\title{
THE SOURCE OF AUTOCRATIC RECALCITRANCE TO SANCTION THREATS
}

\author{
Carl Pi-Cheng Huang \\ Taipei, Taiwan \\ B.A., National Chengchi University, 2012
}

A Thesis presented to the Graduate Faculty of the University of

Virginia in Candidacy for the Degree of Master of Arts

Department of Politics

University of Virginia

December, 2016 


\begin{abstract}
The idea that not all autocracies are alike is increasingly accepted in international relations research. However, compared to the study of war initiation or crisis bargaining, the implication of autocratic regime types is not immediately clear in the study of economic sanctions as a coercive tool of diplomacy. In this paper, I argue that the effectiveness of sanction threats can be explained by the size of domestic audience, which differentiates between personalist targets on the one hand, and non-personalist and democratic targets on the other. Since personalist leaders are less constrained by their domestic audience, personalist targets are less likely to concede to sanction threats compared to other types of regimes. However, this mechanism requires a potential sanction to be costly to the general population, so the relationship is conditioned on the target's trade dependence.
\end{abstract}




\section{Introduction}

Economic sanctions are widely used in foreign policy. In some cases, politicians impose sanctions simply to retaliate or signal disagreements, as in Turkey's trade blockade against Armenia since the Nagorno-Karabakh conflict and the recently ended U.S. embargo against Cuba. ${ }^{1}$ In other cases, politicians use sanctions to gain influence not through outright imposition, but through threats to impose it unless targets meet their demands. When the U.S. threatened Russia with sanction unless it stopped supporting separatists in Ukraine in 2014, it sought to influence Russian policy by making it too costly to stay on its original course. If the economic cost of a potential sanction is perceived to entail high political cost on the leadership, the target leader will have an incentive to avoid it by conceding (Hirschman 1945).

How much a sanction's economic costs can be translated into political costs, in turn, is a function of targets' domestic political institutions. Since a democratic society suffering under sanction is in a better position to punish its leader or remove her from office, previous research suggests that sanctions in general "work" better against democracies (Brooks 2002; Marinov 2005; Lektzian and Souva 2007). If that is correct, then politicians' sanction practices are puzzling: almost all active U.S. sanctions target autocratic regimes. While autocracies on average might be more likely to be targeted with threats due to their foreign policy preferences or human rights practices, if these targets are also less likely to concede, sanction might not be the best available investment of time and resource to if politicians wish to achieve their foreign policy goals.

I argue that the solution to this puzzle lies in the fact that not all autocracies are equally unsusceptible to sanction threats. Although the so-called "personalist" regimes are more

\footnotetext{
1 Another example is the U.S.'s 1951 Trade Agreements Act that put the Soviet bloc outside of America's Reciprocal Trade Program. "That action could hardly do any significant damage to the Soviet bloc, but it was an expression of disapproval.” (Schelling 1958, 489-490).
} 
recalcitrant against senders' demands, other non-democratic regimes under military or single-party rules in fact respond to sanction threats in ways that are more similar to their democratic counterparts. In other words, institutionalized autocracies produce constituencies that can pressure leaders to avoid economic hardship. However, since sanction threats are neither credible nor threatening between countries that do not trade, this relationship requires high trade dependence. Drawing on a dataset of all sanction episodes from 1945 to 2005, I develop an "domestic audience" account to explain the source of personalist targets' recalcitrance against sanctions threats. Finally, I assess the relationship statistically by testing the effect of target regime type on the probability of target concession to sanction threats conditioned by target's high level of trade dependence.

\section{Searching for Sanction Effect}

Situated between "words and war" (Marinov 2005), sanctions allow senders to coerce targets without resorting to actual use of force. While early debate on "whether sanctions work" was criticized by some as a "scholarly limbo" (Baldwin 2000, 80), the question is undoubtedly important and policy-relevant. For senders, sanction's lower financial and political costs compared to military options still come at a price. Indeed, some sanctions inflicted economic burden on the sender that exceeded that on the target (Martin 1992, 56). On the target side, it is usually the most vulnerable part of the population that suffer under sanction (Drury and Peksen 2014). Despite many sanctions' aim at improving human rights, scholars find that imposing sanctions could lead to intensified governmental repressions and more human rights violations in autocracies (Wood 2008; Escribà-Folch 2012). In this context, better understanding of sanction's coercive power can lead to decisions that minimize the collateral damage and maximize the policy's effectiveness. ${ }^{2}$ In

\footnotetext{
${ }^{2}$ For multilateralism see (Drezner 2000), for sender-target antagonism see Drezner (1999), for dispute saliency see Lektzian \& Souva (2007). For sanction type, see Jing et al (2003) For target trade dependence, see (van Bergeijk (1994). One can also find more comprehensive discussions in Bapat et al (2013) "Determinants of Sanctions
} 
particular, democracies more likely to concede to sanctions imposition (Pape 1997, Bolks \& AlSowayel 2000, Allen 2005) or face leadership change after sanctions are imposed (Marinov 2005). ${ }^{3}$

Although previous research on sanction and target regime type provides a good starting point, the institutional variations among non-democracies are left unaddressed. While the canonical conceptualization of regime type as "democracies" versus "non-democracies" has produced an impressive array of research, ${ }^{4}$ useful information can be lost in this dichotomy. Indeed, recent studies show that not all autocracies are alike, and some are systematically different from others in their foreign policy behaviors (for example, Weeks 2008; Weiss 2014). Especially important was Escribà-Folch and Wright's (2010) finding that once sanctions are imposed, leaders of personalist autocracies are more likely to be removed from power compared to leaders of other non-democracies. The result that autocratic targets respond to sanction's destabilization differently due to their institutional variation invites further empirical inquiry that has yet to be explored: if different autocratic regimes behave differently at sanction's "imposition stage," is it possible that the institutional variations also have a role in autocratic leaders decision-making process of whether to concede at "threat stage", that is, when sanction was initially threatened on their countries?

\section{Domestic Audience Size and Leader Recalcitrance}

I argue that the effectiveness of a sanction threat is largely determined by the size of domestic audience. When a target leader is held responsible by a larger group of domestic political audience,

\footnotetext{
Effectiveness: Sensitivity Analysis Using New Data”. International Interactions. Volume 39, Issue 1, 2013

3 Pape (1997), Bolks \& Al-Sowayel (2000), and Allen (2005) find democratic targets more likely to concedes to sanction threats or imposition, while Marinov (2005) find democratic targets are more likely to experience leadership change after sanction imposition. There are some notable exceptions, such as McLean \& Whang's (2010) null-finding and Early's (2011) negative finding.

4 such as the democratic peace theory
} 
her preference is more constrained by the audience's political preference. ${ }^{5}$ Since sanctions are likely to create economic damage on the general population, only leaders with a small set of domestic audience can isolate themselves from public pressure and stand firm against sender's demands. The logic here can be traced back to the selectorate theory (Bueno de Mesquita 2003, Peceny \& Butler 2005): leader continues their political survival by answering to the group that retains her in power (the winning coalition).

The literature on authoritarian regimes agrees that personalist dictators have the smallest size of domestic audience, whereas single-party and military regimes have their size of domestic audience smaller than, but nonetheless more similar to, those in democratic countries. In a personalist state, the government is dominated by "a single individual" as opposed to by a military organization or a hegemonic party (Geddes 1999). As a result, compared to a leader in other non-democracies, a personalist leader has more freedom in pursuing foreign policy goals at her will and faces little consequence even in the case of failure. When being threatened to change her course with sanction, she is also in a better position to stand firm regardless of the potential costs that might be inflicted on the country. An illustrative example is Saddam Hussein's reaction to the comprehensive sanctions imposed against him by the UN Security Council. Although Iraq's total import and exports decreased by a stunning 38.5 billion from 1980 to 1996 (Brooks 2002, 1) and the population's suffering went beyond description, he was in no way constrained by domestic population or elites and there were no visible domestic political consequences for the economic loss caused by his policy.

In addition to allowing the leader to be more indifferent to sanction's potential costs at threat stage, I argue that the small domestic audience size in personalist regimes can also introduce leader recalcitrance into leader's preference. In other words, even if the stakes of the sanction

\footnotetext{
${ }^{5}$ due to the assumption that all leaders seek to stay in power.
} 
threat are high, personalist dictators might become more combative and less reconciliatory. As elaborated by Weeks $(2014,29-30)$, the domestic political structure allows personalist leaders to have greater discretion over "potential spoils" from their revisionist foreign policy. To the extent that potential costs of a sanction threat can be associated with the benefits of non-concession, personalist leaders might have higher incentives to stand firm.

Furthermore, the state-building process of a polity dominated by one individual and the selection of leadership under such a regime favor leaders with a particular "tyrannical" personality featured by international ambition (Weeks 2014), supremacy (Rosen 2005), and self-image (Glad 2002). In sum, even when facing sanction threat with potentially costly consequence, a domestic audience account expects personalist leaders to have a higher probability to stand firm compared to leaders of other regimes.

The domestic audience account presented here also draws insight from the literature on autocratic regimes and use of force. For instance, previous research found that among nondemocratic leaders, personalist dictators are the most likely to initiate disputes with democratic states (Reiter and Stam 2003). Personalist bosses also "initiate conflict more frequently, lose a higher proportion of the wars they start, and yet survive in office at a remarkable rate in the wake of defeat" (Weeks 2014, 7). In the context of economic sanctions, I formulated two testable hypotheses within additional attention to the level of target trade dependence on the sender, as shown in Table 1.

Table 1: Autocratic Regime Type and Sanction Response

\begin{tabular}{|c|c|c|}
\hline & Target = Personalist & $\begin{array}{c}\text { Target }=\text { Democracies or } \\
\text { Non-personalist Autocracies }\end{array}$ \\
\hline High Trade & $\begin{array}{c}\text { Probability of concession to } \\
\text { sanction threat = Low }\end{array}$ & $\begin{array}{c}\text { Probability of concession to } \\
\text { sanction threat = High }\end{array}$ \\
\hline Low Trade & - & - \\
\hline
\end{tabular}


While my main theoretical focus is the domestic political institution of the target regime, including target dependence in the hypotheses is helpful in clarifying under what conditions are personalist targets expected to behave in a systematically different way compared to other targets based on the theory. For instance, cases in which a target is threatened by a sender that it had little or no trade at all might be less relevant to the mechanisms proposed here - since senders in these cases cannot inflict costly economic consequence on the general population thorough cutting down trade, the size of domestic audience in democracies, personalist regimes, and other autocracies does not generate useful predictions on how target respond compared to highdependence scenarios.

The first hypothesis $\left(H_{l}\right)$ seeks to capture the effect of target regime type when a threat is issued by a sender which the target is dependent on in terms of trade. Since the sender clearly has the means to inflict economic cost on target population, the domestic audience mechanism expects democratic targets and other autocratic targets to have a higher probability to concede. Conversely, personalist targets are expected to display recalcitrance, which leads to a lower predictive probability of making concession at threat stage. To ensure that it is the domestic institutional characteristics of personalist regimes specified earlier rather than the unordered democracy-other autocracy-personalist trichotomy that is driving the result, I also develop the second hypothesis $\left(H_{2}\right)$ using a continuous index that measures a country's "personalist level" to test the same theory with high target trade dependence.

Using a cross-sectional data on a total of 834 sanction episodes between sovereign states that started with a sanction threat from 1945 to 2005, this article presents two main findings. First, personalist targets under sanction threats are on average less likely to make policy concessions at threat stage, even after taking factors such as the size of domestic economy, relative material 
capacity, sender-target geographical distance, and factors such as Cold War, United States as the sender, and sender reputation into consideration. As expected, this difference is only observable when target trade dependence on the sender is high. Secondly, when target trade dependence is high, an increase in the personalist characteristic of target state's domestic institution is also associated with lower probability of concession at threat stage. Together, the findings provide support for the domestic audience theory. Consistent with previous research on the influence of domestic politics on international relations, the results show the value in differentiating different types autocratic regimes in order to better understand their foreign policy .

\section{Research Design}

Testing the hypotheses outlined in Table 1 requires a data set that includes information on each sanction episode that took place in the past: what was the target regime type? Was an economic sanction threatened? What was the outcome at threat stage? The best data set for this purpose is the Threat and Imposition of Sanctions (TIES) developed by Morgan, Bapat, Krustev and Kobayashi (2014). I use TIES's data on sanction episodes from 1945 to 2005 and merge it with Barbara Geddes, Joseph Wright, and Erica Frantz's data of autocratic regimes (GWF), which contains country-year information of every country's regime type in a given year from 1946 to 2010 in independent countries with more than one million inhabitants (2014). The visualization of the distribution of target regimes types over year is shown in Figure 1.

Evaluating sanction's effect at threat stage as opposed to imposition stage is more fundamental than switching to a new dependent variable. Due to strategic calculations between sender and target, studying sanction imposition alone might bias us towards underestimating sanction's coercive effect. To paraphrase Schelling's insight on military coercion, sanction could 
be "most purposive and most successful when it is threatened and not used" $(2008,10)$. If a target immediately complies to a sender's sanction threat, "we will never observe the sanction that is responsible for the target's change in policy" (Smith 1995, 241) because sanctions did not even need to be imposed. This problem is identified by scholars such as Nooruddin (2002) as the strategic selection of sanction. Since target at threat stage can "self-select" into imposition stage, it is possible that sanctions are most likely to be imposed on leaders who are relatively unaffected by them or who might actually benefit from them (Bueno de Mesquita \& Smith 2012, 174). In sum, to fully consider sanction's coercive effect, it is necessary to take threat stage into account.

In TIES, a sanction is defined as "actions that one or more countries take to limit or end their economic relations with a target country in an effort to persuade that country to change one or more of its policies." Coders code a sanction episode as begun "when the sender either makes a threat about the possibility of sanctions or imposes sanctions with no previous threat." Since the theoretical focus here is to explain targets' responses to sanction threats, cases in which sanctions are imposed without being threatened are dropped. In TIES, sanction threats also vary by the specificity, types and actors. Some are verbal statements by government officials or draft legislations. Others are passages of conditional law stipulating that sanctions will be imposed if certain target behaviors are not changed. While in some cases primary senders are international organizations in the TIES dataset, this paper limits its cases to those both the senders and targets are sovereign states in order to take sender-target trade dependence into consideration. 
Figure 1: Target Regime Type and Sanction Treat, 1945-2005

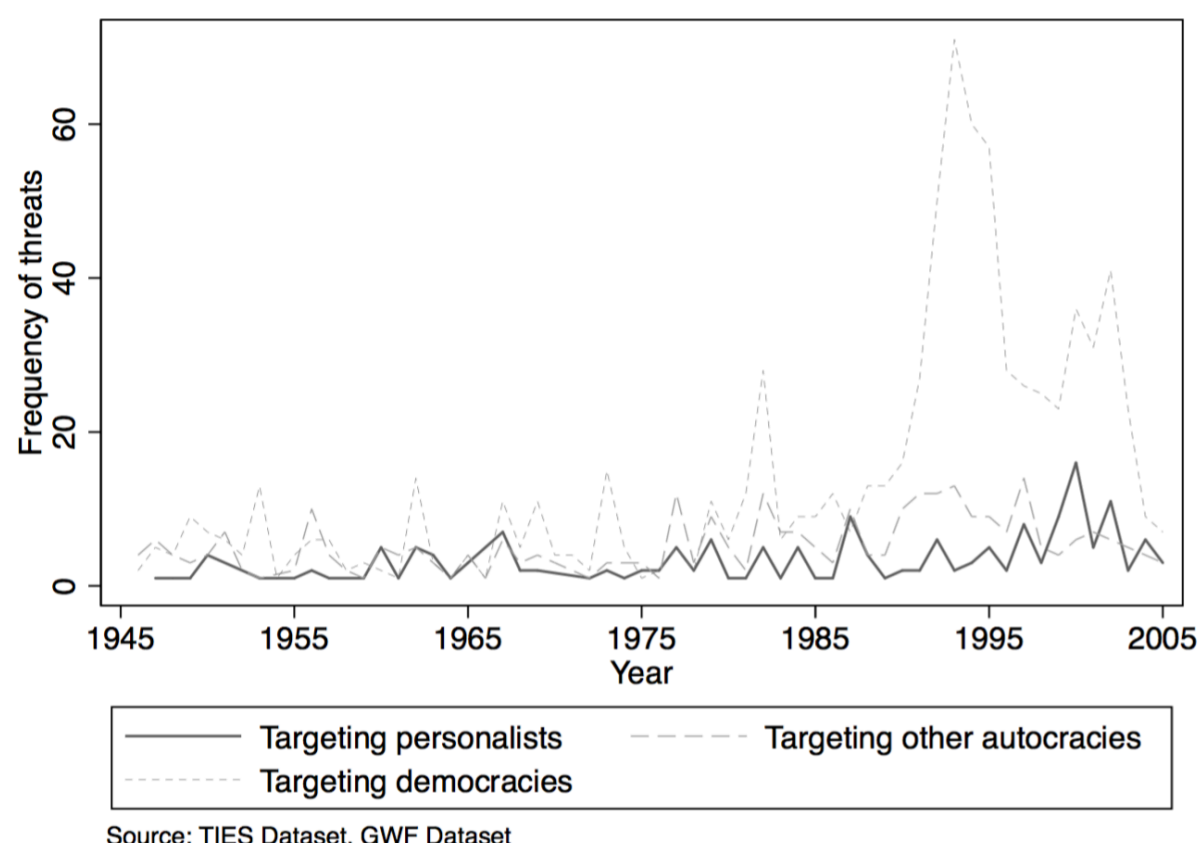

\section{Dependent Variable}

I generate an unordered categorical variable (m_outcome) that takes three values: concession at threat stage $(=1)$, non-concession at threat stage $(=2)$, and imposition $(=3)$. Concession at threat stage is our main category of interests which captures the coercive effect of sanction, that is to say, its capacity to change target behavior when being used as a threat without being imposed. This category is collapsed from the unordered categorical variable "final outcome" in TIES data, as shown in the shaded area in Table 2.

Non-concession at threat stage indicates resolution short of sanction whether the target can get away from sanction threat without making policy concessions or having the sanction imposed on them. As shown in the middle part of Table 2, the results are either stalemate, negotiated settlement, or sender capitulation. Finally, sanction imposition indicates that after issuing threats, 
senders also had to actually impose sanctions to achieve their desired results. In other words, this implies sender's coercive failure at threat stage.

While "concession at threat stage" and "imposition" are related, it is worth noting that they are not expected to be always complimentary. If target concedes to sanction threat, it is clear that sanction will not be imposed. If the target refuses to concede, however, sanction imposition does not always follow. First, sender might have bluffed and actually did not have enough economic or political capital to impose what was being threatened. As imposition can lead to both success and failure, sender might also update its belief about target's resolve and its own chance of success based on their interactions and decide not to enter the imposition stage even if it was capable. Change of situation such as domestic political atmosphere might also influence sender's resolve. Hence, although the domestic audience theory predicts that sanction threats targeting personalist leaders with high trade dependence are unlikely to succeed, it is unclear whether senders against those target are also systematically more resolved to carry out the imposition compared to senders against other type of targets.

\section{Independent Variables}

1.1 Target regime - Target regime type, the main independent variable in this study, is derived from Barbara Geddes's research on authoritarianism (Geddes 2003, 225-232). In the coding process of GWF data, coders are instructed to ask several dichotomous questions about the basic characteristics of a particular regime (e.g. Afghanistan 1973-78, Albania 1946-91). Each autocratic regime type has its own set of questions. For instance, there are 12 questions for Personalism, 15 for single-party regime, and 12 for military regime. If the number of "yes" appears in more than half of the "personalist" questions for a regime, the coder would code the 
country as "personalist" within that period. For further reference, all the questions are listed in the Appendix. While this coding scheme allows an autocratic regime to fit in all three main categories at the same time, I only focus on the personalist/non-personalist distinction among autocracies. Thus, regimes meeting the personalist requirements are viewed as "Personalist" regardless of their possible hybridity. Those meeting only other autocratic conditions are viewed as "Non-personalist Autocracies" and are primarily single-party and military regimes, whereas the rest are "Democracies."

1.2 Personalist Index - some readers might be concerned with whether the use of trichotomy can fully capture the institutional variations in autocratic regimes. Indeed, Geddes's original categorization of autocratic regimes are less clear cut and borderline cases such as personalist-military and personalist-single party regimes are certainly less "personalist" than regimes that are unambiguously "personalist." Thus, I further test the effect of autocratic regime type on target response to sanction threat using a continuous measurement of "personalism" developed by Weeks (2014, see 47-48) from Geddes's raw data. The index score is continuous with a lower bound of 0 and an upper bound of 1 . Whereas 0 indicates the regime of a given year showed no personalist characteristics, the value 1 indicates that a regime was fully personalist according to Geddes's definition. The advantages are two-fold. First, since a continuous index does not force any regime to be strictly personalist or non-personalist, one can avoid losing potentially important information when drawing categorical cut points. Second, the continuous index allows us to estimate not only the categorical effect personalist targets have compared to non-personalist targets, but also the effect of incremental institutional change target regime type can have. For instance, researchers can estimate whether a change in personalist index of a target from 0.6 to 0.8 is also associated with a higher level of recalcitrance. This alternative measurement can also be 
seen as a robustness check of whether it is really personalism that is doing the explanatory work.

2. Target trade dependence - since the explanatory power of the domestic audience account depends on how well a target leader can isolate herself from a population that might suffer under economic sanction, I use target's trade dependence on the sender to capture the economic costs that a threatened sanction can inflict on the target population if it is actually imposed. If target and sender never trade with each other, it is more reasonable to assume that the coercive power of a sanction threat is not based on my theoretical mechanism regardless of whether the target capitulated or not. On the other hand, in a hypothetical situation that a target is threatened by its only trade partner with sanction, it is safer to assume that a sanction can really hurt the leader given a larger domestic audience size. In other words, although trade dependence is not a part of the domestic audience theory, the theory only predicts autocratic regime type to have an effect when target trade dependence on sender is high.

Measuring target trade dependence can be tricky and there is more than one way of operationalization. I rely on the Barbieri's (1996) concept of trade share, which is built on Hirschman's original concept of "trade index." According to Barbieri, "trade share measures the proportion of dyadic trade over total trade, both import and export flows, for each state with its trading partners" (36). To calculate the trade dependence of target " $i$ " on sender " $j$," I divide the two countries' bilateral trade flows by the total trade volume of the target. The variable "target trade share" is generated using the Bilateral Trade (v3.0) data set from the Correlates of War project (Barbieri \& Keshk 2012), which contains all the dyadic trade and national trade data from 1870 to 2009. As robustness check, I also use another conceptualization of target trade share that only take the proportion of target exports to sender to target's national export, but our interested results remains unchanged. 


$$
\text { Trade Share }_{i}=\frac{\text { Dyadic } \text { Trade }_{i j}}{\text { Total Trade }_{i j}}
$$

In addition to the COW trade data, I also use the International Trade Statistics Database of the United Nations (UN Comtrade) as robustness check. While UN Comtrade arguably has the trade data with the best quality, trade data prior to 1960 are not available. Neither does UN Comtrade have trade information of non-UN members such as Taiwan. To address this issue, I conduct the same analysis on two versions the UN Comtrade: the original version and a new version that uses (1) the target trade volume from the COW data set and (2) target GDP from World Bank to impute the missing values in UN Comtrade. ${ }^{6}$ As shown in the Appendix, while COW trade data yields the strongest result, results from both versions of UN Comtrade data are statistically significant and substantively consistent with the theory. In the core model presented in the later section, I use the logged version of target trade dependence using the COW data.

3. Economic conditions of sender and target - the size of the economies of both the sender and target might be related to their behaviors in a sanction episode. For instance, a sender with large domestic economy might be in a better position to actually impose economic sanction if the target chooses to stand firm, therefore projecting a higher credibility when it issues a threat. Additionally, as pointed out by Wright, "personalist rule is more likely in countries with smaller populations, less investment, and larger oil reserves" $(2008,325)$. As a result, a target country's small economy and oil dependency might together "select" a personalist rule while also leading to a particular sanction result. To mitigate this concern, I include the GDP of the target and sender in the model and a binary variable indicating whether the target is a "petro state". I rely on World

\footnotetext{
${ }^{6}$ Leaving list-wise deletion unaddressed can also potentially biased the result because data availability of economic data tends to associate with the size and development of an economy. For more discussion of the potential threats of the "advanced democracy bias" in economic data, see Lall's "How Multiple Imputation Makes a Difference" (forthcoming)
} 
Bank data for GDP and Colgan's (2013) data set for the petro state variable.

4. CINC Score - in the sanction literature, sender's power relative to target is seen as an important factor to the outcome (Bapat et al 2013), so I include the difference in the national material capabilities between sender and target operationalized by the ratio of sender-target CINC score (Singer 1987). Each sanction episode also has different level of geopolitical relevance which can be revealed by the geographical information between sender and target. For instance, a threat made by a neighboring state might be more politically salient and consequential compared to a threat made by a state that is far and away. I seek to capture such nuance using the distance between capital cities of the sender and the target developed by Kristian Gleditsch.

5. United States and the Cold War - in TIES, more than half of the sanction threats are issued by one single actor: The United States. There are reasons to believe that the U.S. as a sender might systematically choose different types of target or lead to a particular type of sanction outcome, if not both. To take this into account, I use a binary variable to indicate whether it was the United States that issued the sanction threat in an episode. Another factor to consider is whether an episode occurred during or after the Cold War. Since the Cold War era is featured by a particular global distribution of power, the essence of sanction threats might be different during and post-Cold War. Indeed, scholars have found that the end of Cold War has “increased governments willingness to impose sanctions (Martin 2000, 17). Thus I also control for whether the episode started during $(=1)$ or after $(=0)$ the Cold War period.

6. Issue type, Sanction type, and Institution - To avoid treating all sanction threats as the same, I differentiate them in terms of issue areas, mentions of use of specific policy tools, and involvements of international organizations. For issue areas, I recoded the variable "issue type" in TIES into three binary variables that indicates whether a sanction threat is (a) security-related, 
(b) trade-related, or (c) human-rights related and allows multiple memberships. In the sanction literature, it has been well-established that some types of sanctions, especially financial and targeted sanctions (also known as "smart sanctions"), are different from others in terms of effectiveness (Dashti-Gibson et al. 1997; Morgan and Schwebach 1997; Cortright and Lopez 1998; Hufbauer et al. 2007; Drezner 2015). Following the operationalization summarized by Bapat et al. (2013), I code a sanction episode as "financial" if the threatened sanction included aid terminations or asset freezes, and as "targeted" if the sender's intention includes targeting the regime leadership, business interests, or the military. While scholarly assessments of multilateral sanction's effectiveness are mixed (see Drezner 2001), I use the binary variable "institution" to record whether an international institution is involved during threat stage.

7. Past success and multiple sanctions - as in any generalized linear model that seeks to find a set of parameter values that maximizes the joint probability of observations and find support that our data is indeed a result from the proposed generating process, the statistical model here requires the Independent and identically distributed assumption (IID) to be at least conditionally satisfied. That is, after taking all independent variables into account, the outcome of each sanction episode should be independent from each other. Although it is extremely difficult in social science to categorically ensure that IID is met, there are two additional variables I also control for in order to alleviate such concern. First, from the target's point of view, sender's success in previous sanction episodes against other targets (or the same target) might establish a reputation and influence its decision of whether to concede in the current episode. Perhaps the more successful a sender was in making target concede in the past, the more likely for its threats to succeed today. Therefore, I use a binary variable "past success" to indicate whether the outcome of the sender's previous threat led to sender's concession at threat stage $(=1)$ or not $(=0)$. 
Another spill-over effect that a sanction episode might create can occur when a target found itself simultaneously in more than one episode. If a target was already under sanction by another sender while a new sanction threat was issued against it, the target might had already been weakened by the sanction imposition and decide to cave in to a threat that it might have otherwise stood firm against. In some situations, scholars such as Early (2011) find that multiple sanction episodes to be an important factor in explaining target behavior. To account for this potential effect, I generate a binary variable "multiple" that take the value of 1 if the sanction threat was issued on a target prior to the "end date" of the previous sanction imposition.

8. sender regime - Finally, drawing from the audience cost literature, sender's domestic political institution might signal important information about whether a threat is credible. Through the same logic of domestic audience size hypothesis I presented earlier, since democracies have a larger domestic political audience, leaders might find themselves more vulnerable to the public's ex-post punishment if she bluffed and hurt the country's reputation. While it is important to note that recent research (see Downes \& Sechser 2012) has put question marks on whether this is really the case when one look at cases of "true compellence threats," I use the same Geddes's trichotomy for the sender to account for this potential effect.

\section{Methodology}

I test both hypotheses $\left(H_{1}\right.$ and $H_{2}$ in Table 1$)$ against empirical data using multinomial logistic regression. Since coefficients in generalized linear regressions are harder to interpret substantively from the table and the additional interaction in the linear model further complicates the numeric results, I attached the coefficient tables in the Appendix and present the results graphically. Figure 1 shows the interaction between target regime type and trade dependence on the probability of target concession at threat stage. As shown in the first row, democratic targets and non-personalist 
autocratic targets display similar tendency: as target dependence varies from low to high, the probability of concession increases despite not at the $95 \%$ level of statistical significance (for democracy target, the F-test returns a p-value of 0.084). On the other hand, while personalist targets are no less likely to concede compared to other target regime types when trade dependence is zero, they are predicted to be much more recalcitrant when they trade extensively with the sender.

Table 1: Coefficients Table for Models with different Trade Data \& Dependence Operationalization

\begin{tabular}{|c|c|c|c|c|c|}
\hline $\begin{array}{l}\text { Multinomial Outcome }=\text { Concession } \\
\text { (base outcome: Non-concession at threat } \\
\text { stage) }\end{array}$ & $\begin{array}{l}\text { Model (1): } \\
\text { COW Trade }\end{array}$ & $\begin{array}{l}\text { Model (2) : } \\
\text { UN Comtrade }\end{array}$ & $\begin{array}{c}\text { Model (3) : } \\
\text { Alternative } \\
\text { COW }\end{array}$ & $\begin{array}{c}\text { Model (4) : } \\
\text { Alternative UN }\end{array}$ & $\begin{array}{l}\text { Model (5) : } \\
\text { UN Imputed }\end{array}$ \\
\hline Trade & $\begin{array}{l}-5.066 \\
(3.736)\end{array}$ & $\begin{array}{l}-3.802 \\
(3.767)\end{array}$ & $\begin{array}{l}-3.836 \\
(2.102)\end{array}$ & $\begin{array}{l}-3.449 \\
(2.652)\end{array}$ & $\begin{array}{l}-3.605 \\
(2.361)\end{array}$ \\
\hline (Target $=$ Democracy) $\times$ Trade & $\begin{array}{c}7.227 \\
(3.922)\end{array}$ & $\begin{array}{c}4.383 \\
(3.858)\end{array}$ & $\begin{array}{c}3.993 \\
(2.243)\end{array}$ & $\begin{array}{c}3.783 \\
(2.787)\end{array}$ & $\begin{array}{c}4.823 \\
(2.486)\end{array}$ \\
\hline (Target $=$ Other Autocracy) $\times$ Trade & $\begin{array}{c}7.077 \\
(4.123)\end{array}$ & $\begin{array}{c}5.188 \\
(3.988)\end{array}$ & $\begin{array}{c}4.116 \\
(2.334)\end{array}$ & $\begin{array}{c}4.832 \\
(2.955)\end{array}$ & $\begin{array}{c}4.053 \\
(2.677)\end{array}$ \\
\hline Target $=$ Democracy & $\begin{array}{l}-1.096 \\
(0.629)\end{array}$ & $\begin{array}{l}-0.698 \\
(0.709)\end{array}$ & $\begin{array}{l}-0.930 \\
(0.546)\end{array}$ & $\begin{array}{l}-0.646 \\
(0.642)\end{array}$ & $\begin{array}{l}-1.031 \\
(0.585)\end{array}$ \\
\hline Target $=$ Other Autocracy & $\begin{array}{l}-1.306 \\
(0.725)\end{array}$ & $\begin{array}{l}-1.182 \\
(0.798)\end{array}$ & $\begin{array}{l}-1.041 \\
(0.595)\end{array}$ & $\begin{array}{l}-1.186 \\
(0.738)\end{array}$ & $\begin{array}{l}-1.017 \\
(0.647)\end{array}$ \\
\hline Target GDP & $\begin{array}{c}3.11 \mathrm{e}-14 \\
(6.44 \mathrm{e}-14)\end{array}$ & $\begin{array}{c}3.46 \mathrm{e}-14 \\
(6.85 \mathrm{e}-14)\end{array}$ & $\begin{array}{c}4.73 \mathrm{e}-14 \\
(6.40 \mathrm{e}-14)\end{array}$ & $\begin{array}{c}3.54 \mathrm{e}-14 \\
(6.86 \mathrm{e}-14)\end{array}$ & $\begin{array}{c}4.73 \mathrm{e}-14 \\
(6.41 \mathrm{e}-14)\end{array}$ \\
\hline Sender GDP & $\begin{array}{l}-9.61 e-14 \\
(8.53 e-14)\end{array}$ & $\begin{array}{l}-3.97 \mathrm{e}-14 \\
(1.01 \mathrm{e}-13)\end{array}$ & $\begin{array}{l}-8.87 e-14 \\
(8.48 \mathrm{e}-14)\end{array}$ & $\begin{array}{l}-3.50 \mathrm{e}-14 \\
(1.01 \mathrm{e}-13)\end{array}$ & $\begin{array}{l}-9.81 \mathrm{e}-14 \\
(8.46 \mathrm{e}-14)\end{array}$ \\
\hline Financial Sanction & $\begin{array}{l}0.0209 \\
(0.387)\end{array}$ & $\begin{array}{l}-0.114 \\
(0.430)\end{array}$ & $\begin{array}{c}-0.0548 \\
(0.386)\end{array}$ & $\begin{array}{l}-0.143 \\
(0.430)\end{array}$ & $\begin{array}{l}-0.0858 \\
(0.381)\end{array}$ \\
\hline Targeted Sanction & $\begin{array}{c}0.224 \\
(0.323)\end{array}$ & $\begin{array}{c}0.162 \\
(0.366)\end{array}$ & $\begin{array}{c}0.235 \\
(0.323)\end{array}$ & $\begin{array}{c}0.160 \\
(0.366)\end{array}$ & $\begin{array}{c}0.260 \\
(0.321)\end{array}$ \\
\hline Capital Distance & $\begin{array}{c}0.0000605 \\
(0.0000390)\end{array}$ & $\begin{array}{c}0.0000350 \\
(0.0000440)\end{array}$ & $\begin{array}{c}0.0000311 \\
(0.0000379)\end{array}$ & $\begin{array}{c}0.0000311 \\
(0.0000429)\end{array}$ & $\begin{array}{c}0.0000499 \\
(0.0000381)\end{array}$ \\
\hline Issue type $=$ Security & $\begin{array}{l}-0.787 \\
(0.443)\end{array}$ & $\begin{array}{c}-1.084^{*} \\
(0.505)\end{array}$ & $\begin{array}{l}-0.804 \\
(0.441)\end{array}$ & $\begin{array}{c}-1.076^{*} \\
(0.504)\end{array}$ & $\begin{array}{l}-0.789 \\
(0.441)\end{array}$ \\
\hline Issue type $=$ Economic & $\begin{array}{l}-0.716 \\
(0.567)\end{array}$ & $\begin{array}{l}-0.555 \\
(0.635)\end{array}$ & $\begin{array}{l}-0.777 \\
(0.570)\end{array}$ & $\begin{array}{l}-0.550 \\
(0.636)\end{array}$ & $\begin{array}{l}-0.753 \\
(0.569)\end{array}$ \\
\hline Issue type $=$ Human Rights & $\begin{array}{l}-0.661 \\
(0.402)\end{array}$ & $\begin{array}{l}-0.621 \\
(0.457)\end{array}$ & $\begin{array}{l}-0.593 \\
(0.400)\end{array}$ & $\begin{array}{l}-0.605 \\
(0.456)\end{array}$ & $\begin{array}{l}-0.691 \\
(0.398)\end{array}$ \\
\hline National Material Capabilities Ratio & $\begin{array}{c}0.00465 * * \\
(0.00155)\end{array}$ & $\begin{array}{c}0.00456 * * \\
(0.00160)\end{array}$ & $\begin{array}{c}0.00487 * * \\
(0.00161)\end{array}$ & $\begin{array}{c}0.00486 * * \\
(0.00168)\end{array}$ & $\begin{array}{c}0.00472 * * \\
(0.00152)\end{array}$ \\
\hline Post-Cold War threat & $\begin{array}{l}0.0180 \\
(0.389)\end{array}$ & $\begin{array}{l}-0.0996 \\
(0.439)\end{array}$ & $\begin{array}{l}-0.0735 \\
(0.385)\end{array}$ & $\begin{array}{l}-0.128 \\
(0.439)\end{array}$ & $\begin{array}{c}-0.0226 \\
(0.386)\end{array}$ \\
\hline Sender $=$ USA & $\begin{array}{c}0.237 \\
(0.744)\end{array}$ & $\begin{array}{c}0.143 \\
(0.901)\end{array}$ & $\begin{array}{c}0.582 \\
(0.736)\end{array}$ & $\begin{array}{c}0.142 \\
(0.893)\end{array}$ & $\begin{array}{c}0.440 \\
(0.734)\end{array}$ \\
\hline Multilateral Institution involved & $\begin{array}{l}0.823^{*} \\
(0.414)\end{array}$ & $\begin{array}{l}1.138^{*} \\
(0.468)\end{array}$ & $\begin{array}{c}0.794 \\
(0.410)\end{array}$ & $\begin{array}{l}1.140^{*} \\
(0.470)\end{array}$ & $\begin{array}{c}0.779 \\
(0.408)\end{array}$ \\
\hline Sender $=$ Other Autocracy & $\begin{array}{l}-0.870 \\
(0.635)\end{array}$ & $\begin{array}{l}-1.075 \\
(0.768)\end{array}$ & $\begin{array}{l}-0.943 \\
(0.630)\end{array}$ & $\begin{array}{l}-1.088 \\
(0.769)\end{array}$ & $\begin{array}{l}-0.981 \\
(0.628)\end{array}$ \\
\hline
\end{tabular}




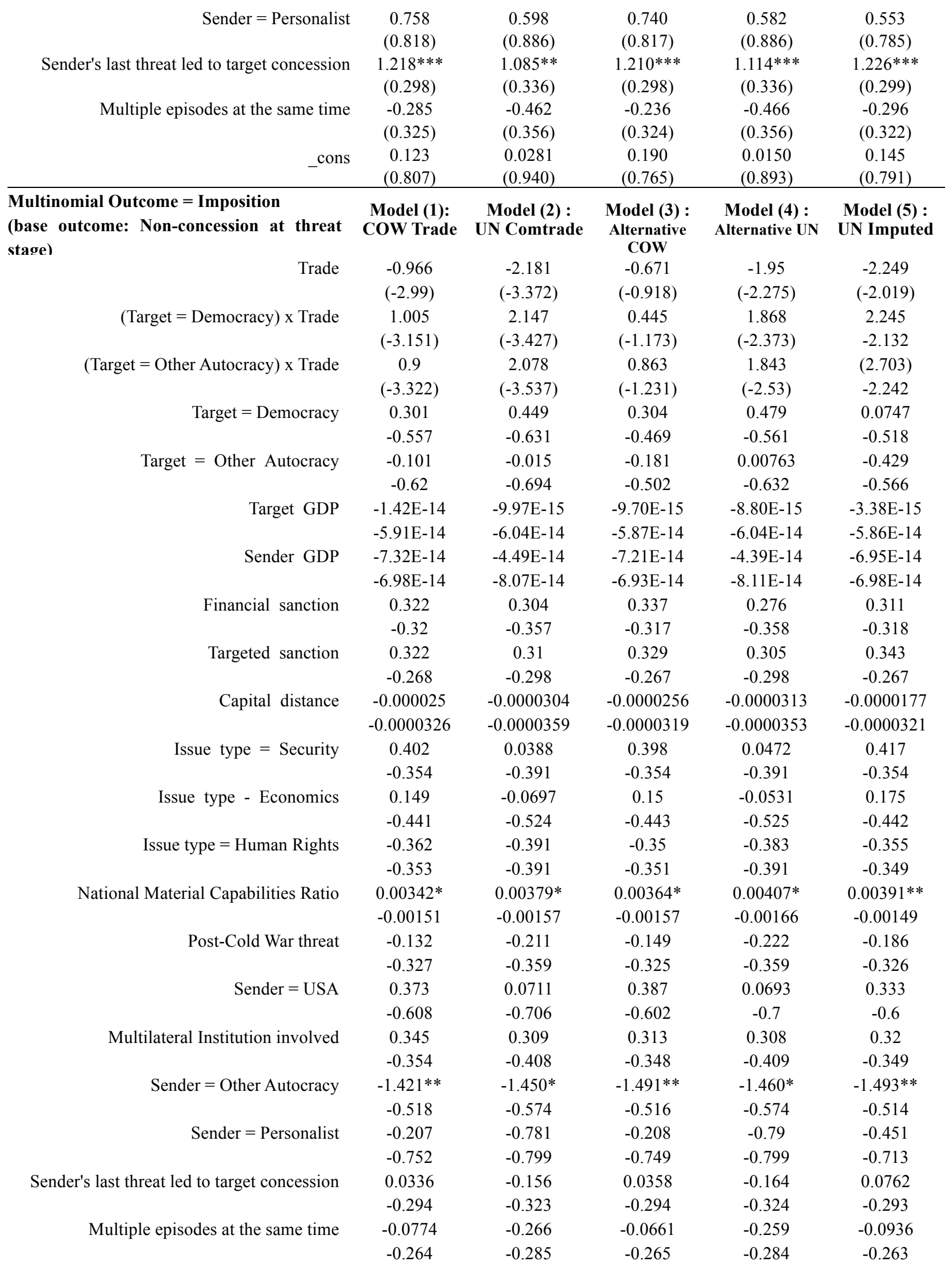


Using "personalist target" as the base category, Figure 2 shows the marginal effect of target regime type when the target is a democracy (on the left) or other autocracy (on the right) compared to a personalist regime (the zero base line) at different levels of trade dependence. As logged target trade dependence increases, the effect of "democratic target" and "other autocratic target" becomes positive and statistically significant compared to the personalist target. This result is consistent with the result from Figure 1.

\section{Figure 1 - Predicted Probability of Target Concession When Target Trade Dependence to the sender increases from minimum to maximum}

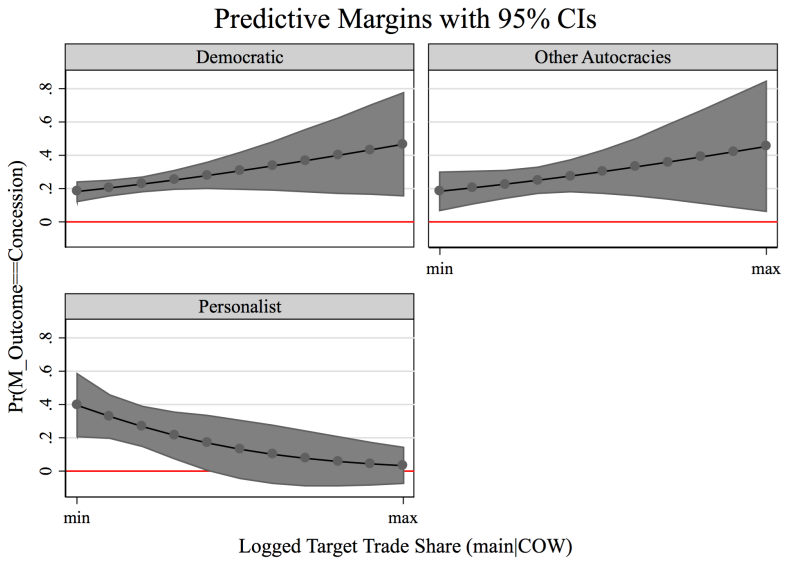

COW Trade

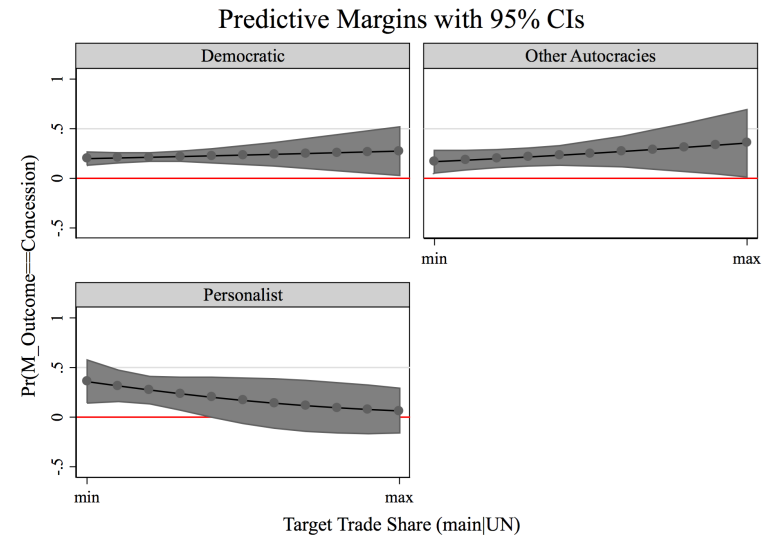

UN Comtrade

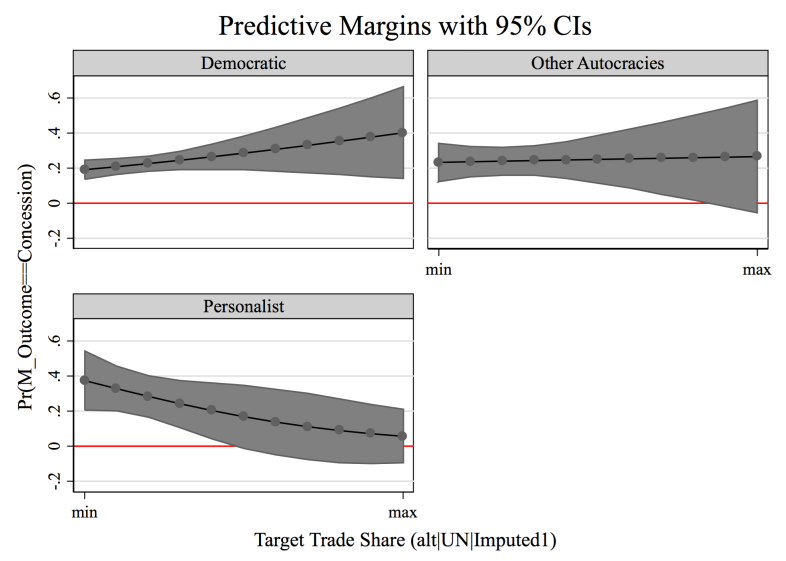

(UN Comtrade- imputed) 
Figure 2- Marginal Effect of Target Regime Type (Base category = personalist) When Logged Target Trade Dependence to the sender increases from minimum to maximum $($ Trade $=$ COW $)$

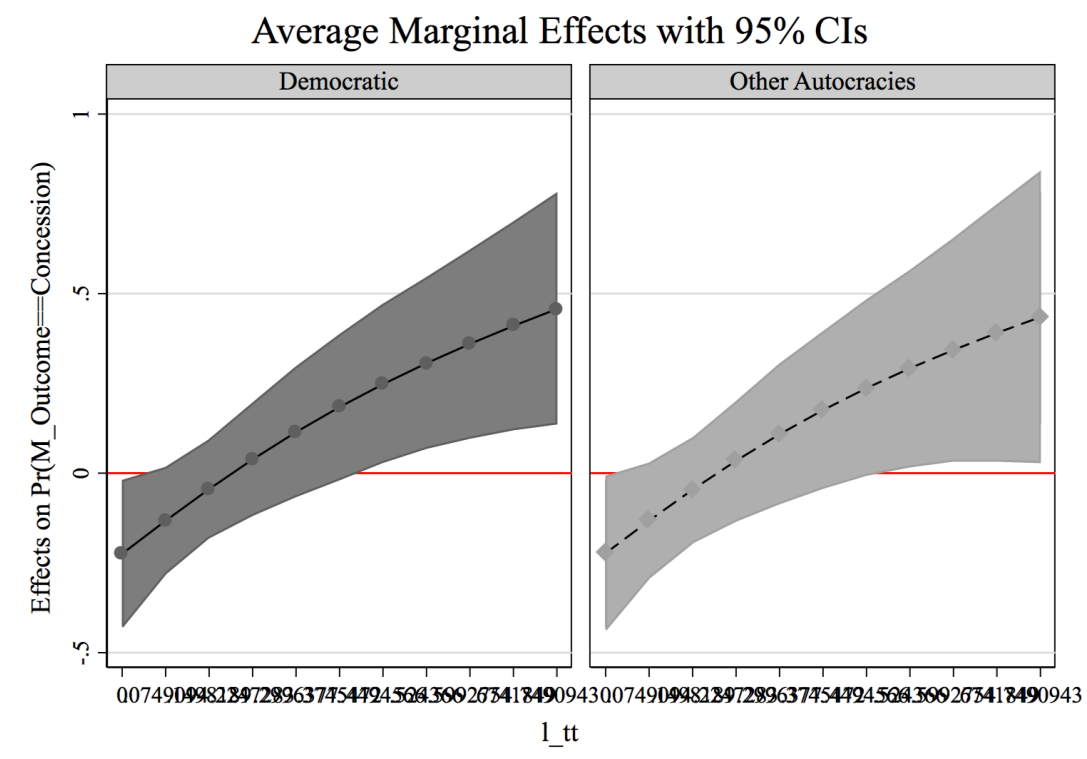

One can also look at the effect of target regime type from a continuous scale and see whether the result can indeed be explained by the incremental changes in the personalist characteristics within target's domestic political institution. Figure 3 provides the predicted probability when target regime type varies from 0 to 1 at three different levels of trade dependence. While an increase in target personalism does not make a difference when trade dependence with sender is low (except that the confidence interval becomes larger when personalism approaches 1 , which might be an unintended result from the fact that there are fewer personalist cases in the data set), the last sub-figure provides evidence that under high trade dependence, targets are indeed expected to be more recalcitrant when they are more "personalist." The result is consistent with the second hypothesis $\left(\mathrm{H}_{2}\right)$. 
Table 2: Coefficients Table for 5 Models with different Trade Data and Trade Dependence Operationalization with Personalist Index

\begin{tabular}{|c|c|c|c|c|c|}
\hline $\begin{array}{l}\text { Multinomial Outcome }=\text { Concession } \\
\text { (base outcome: Non-concession at threat } \\
\text { stage) }\end{array}$ & $\begin{array}{l}\text { Model (1): } \\
\text { COW Trade }\end{array}$ & $\begin{array}{c}\text { Model (2): } \\
\text { UN Comtrade }\end{array}$ & $\begin{array}{l}\text { Model (3) : } \\
\text { Alternative } \\
\text { COW }\end{array}$ & $\begin{array}{c}\text { Model (4) : } \\
\text { Alternative UN }\end{array}$ & $\begin{array}{l}\text { Model (5) : } \\
\text { UN Imputed }\end{array}$ \\
\hline \multirow[t]{2}{*}{ Trade } & 1.404 & 0.681 & 0.141 & 0.561 & 0.972 \\
\hline & $(1.171)$ & $(1.064)$ & $(0.667)$ & $(0.920)$ & $(0.766)$ \\
\hline \multirow[t]{2}{*}{ (Personalist index) $\mathrm{x}$ Trade } & -5.314 & -5.821 & -2.330 & -4.718 & -3.528 \\
\hline & $(5.198)$ & $(7.229)$ & $(2.061)$ & $(5.102)$ & $(3.122)$ \\
\hline \multirow[t]{2}{*}{ Personalist index } & 0.287 & -0.0276 & 0.163 & -0.108 & 0.270 \\
\hline & $(0.976)$ & $(1.549)$ & $(0.808)$ & $(1.348)$ & $(0.996)$ \\
\hline \multirow[t]{2}{*}{ Target GDP } & $3.10 \mathrm{e}-14$ & $4.05 \mathrm{e}-14$ & $3.87 \mathrm{e}-14$ & $4.11 \mathrm{e}-14$ & $3.94 \mathrm{e}-14$ \\
\hline & $(6.16 \mathrm{e}-14)$ & $(6.68 \mathrm{e}-14)$ & $(6.15 \mathrm{e}-14)$ & $(6.69 \mathrm{e}-14)$ & $(6.16 \mathrm{e}-14)$ \\
\hline \multirow[t]{2}{*}{ Sender GDP } & $-7.78 \mathrm{e}-14$ & $-4.18 \mathrm{e}-14$ & $-7.31 \mathrm{e}-14$ & $-3.96 e-14$ & $-8.42 \mathrm{e}-14$ \\
\hline & $(8.14 \mathrm{e}-14)$ & $(9.94 \mathrm{e}-14)$ & $(8.12 \mathrm{e}-14)$ & $(9.97 \mathrm{e}-14)$ & $(8.16 \mathrm{e}-14)$ \\
\hline \multirow[t]{2}{*}{ Financial sanction } & 0.269 & -0.0513 & 0.191 & -0.0675 & 0.184 \\
\hline & $(0.359)$ & $(0.424)$ & $(0.355)$ & $(0.424)$ & $(0.358)$ \\
\hline \multirow[t]{2}{*}{ Targeted sanction } & 0.259 & 0.249 & 0.263 & 0.252 & 0.274 \\
\hline & $(0.311)$ & $(0.361)$ & $(0.311)$ & $(0.361)$ & $(0.311)$ \\
\hline \multirow[t]{2}{*}{ Capital distance } & 0.0000298 & 0.0000201 & 0.0000139 & 0.0000181 & 0.0000310 \\
\hline & $(0.0000365)$ & $(0.0000435)$ & $(0.0000358)$ & $(0.0000422)$ & $(0.0000363)$ \\
\hline \multirow[t]{2}{*}{ Issue type $=$ Security } & -0.786 & $-1.037 *$ & -0.808 & $-1.030^{*}$ & -0.780 \\
\hline & $(0.430)$ & $(0.492)$ & $(0.428)$ & $(0.492)$ & $(0.430)$ \\
\hline \multirow[t]{2}{*}{ Issue type - Economics } & -0.880 & -0.693 & -0.883 & -0.700 & -0.825 \\
\hline & $(0.563)$ & $(0.629)$ & $(0.566)$ & $(0.628)$ & $(0.563)$ \\
\hline \multirow[t]{2}{*}{ Issue type $=$ Human Rights } & -0.760 & -0.718 & -0.717 & -0.705 & $-0.760 *$ \\
\hline & $(0.389)$ & $(0.446)$ & $(0.387)$ & $(0.445)$ & $(0.387)$ \\
\hline \multirow[t]{2}{*}{ National Material Capabilities Ratio } & $0.00212 *$ & $0.00387 *$ & $0.00230 *$ & $0.00412 * *$ & $0.00245^{*}$ \\
\hline & $(0.00107)$ & $(0.00153)$ & $(0.00111)$ & $(0.00159)$ & $(0.00110)$ \\
\hline \multirow[t]{2}{*}{ Post-Cold War threat } & -0.0415 & -0.0910 & -0.0816 & -0.104 & -0.0433 \\
\hline & $(0.377)$ & $(0.430)$ & $(0.374)$ & $(0.430)$ & $(0.375)$ \\
\hline \multirow[t]{2}{*}{ Sender $=$ USA } & 0.411 & 0.268 & 0.615 & 0.262 & 0.514 \\
\hline & $(0.715)$ & $(0.886)$ & $(0.707)$ & $(0.878)$ & $(0.709)$ \\
\hline \multirow[t]{2}{*}{ Multilateral Institution involved } & $0.857^{*}$ & $1.112 *$ & $0.814^{*}$ & $1.107 *$ & $0.842 *$ \\
\hline & $(0.402)$ & $(0.464)$ & $(0.399)$ & $(0.464)$ & $(0.399)$ \\
\hline \multirow[t]{2}{*}{ Sender $=$ Other Autocracy } & -0.653 & -1.116 & -0.733 & -1.119 & -0.746 \\
\hline & $(0.589)$ & $(0.752)$ & $(0.586)$ & $(0.753)$ & $(0.586)$ \\
\hline \multirow[t]{2}{*}{ Sender $=$ Personalist } & 0.766 & 0.547 & 0.743 & 0.545 & 0.568 \\
\hline & $(0.808)$ & $(0.864)$ & $(0.808)$ & $(0.864)$ & $(0.776)$ \\
\hline \multirow[t]{2}{*}{ Sender's last threat led to target concession } & $1.177 * * *$ & $1.062 * *$ & $1.175 * * *$ & $1.082 * *$ & $1.178 * * *$ \\
\hline & $(0.289)$ & $(0.329)$ & $(0.289)$ & $(0.329)$ & $(0.289)$ \\
\hline \multirow[t]{2}{*}{ Multiple episodes at the same time } & -0.314 & -0.480 & -0.293 & -0.483 & -0.332 \\
\hline & $(0.311)$ & $(0.345)$ & $(0.310)$ & $(0.345)$ & $(0.309)$ \\
\hline \multirow[t]{2}{*}{ _cons } & -0.680 & -0.602 & -0.523 & -0.594 & -0.685 \\
\hline & $(0.608)$ & $(0.694)$ & $(0.597)$ & $(0.688)$ & $(0.602)$ \\
\hline
\end{tabular}




\begin{tabular}{|c|c|c|c|c|c|}
\hline $\begin{array}{l}\text { Multinomial Outcome }=\text { Imposition } \\
\text { (base outcome: Non-concession at threat } \\
\text { stage) }\end{array}$ & $\begin{array}{l}\text { Model (1): } \\
\text { COW Trade }\end{array}$ & $\begin{array}{l}\text { Model (2) : } \\
\text { UN Comtrade }\end{array}$ & $\begin{array}{l}\text { Model (3) : } \\
\text { Alternative } \\
\text { COW }\end{array}$ & $\begin{array}{c}\text { Model (4) : } \\
\text { Alternative UN }\end{array}$ & $\begin{array}{l}\text { Model (5) : } \\
\text { UN Imputed }\end{array}$ \\
\hline \multirow[t]{2}{*}{ Trade } & -0.459 & -0.253 & -0.249 & -0.275 & -0.0556 \\
\hline & $(0.995)$ & $(0.854)$ & $(0.601)$ & $(0.756)$ & $(0.656)$ \\
\hline \multirow[t]{2}{*}{ (Personalist index $) \times$ Trade } & 0.245 & 0.175 & -0.274 & -0.913 & -1.905 \\
\hline & $(3.805)$ & $(4.791)$ & $(1.123)$ & $(2.913)$ & $(2.444)$ \\
\hline \multirow[t]{2}{*}{ Personalist index } & -0.336 & -0.699 & -0.149 & -0.437 & 0.199 \\
\hline & $(0.804)$ & $(1.190)$ & $(0.641)$ & $(0.990)$ & $(0.811)$ \\
\hline \multirow[t]{2}{*}{ Target GDP } & $1.53 \mathrm{e}-14$ & $1.21 \mathrm{e}-14$ & $1.73 \mathrm{e}-14$ & $1.42 \mathrm{e}-14$ & $2.29 \mathrm{e}-14$ \\
\hline & $(5.65 \mathrm{e}-14)$ & $(5.85 \mathrm{e}-14)$ & $(5.64 \mathrm{e}-14)$ & $(5.86 \mathrm{e}-14)$ & $(5.63 \mathrm{e}-14)$ \\
\hline \multirow[t]{2}{*}{ Sender GDP } & $-4.90 e-14$ & $-3.78 \mathrm{e}-14$ & $-4.99 e-14$ & $-3.58 \mathrm{e}-14$ & $-5.05 e-14$ \\
\hline & $(6.89 \mathrm{e}-14)$ & $(8.03 e-14)$ & $(6.85 \mathrm{e}-14)$ & $(8.07 e-14)$ & $(6.86 \mathrm{e}-14)$ \\
\hline \multirow[t]{2}{*}{ Financial sanction } & 0.371 & 0.316 & 0.395 & 0.286 & 0.370 \\
\hline & $(0.307)$ & $(0.356)$ & $(0.305)$ & $(0.357)$ & $(0.307)$ \\
\hline \multirow[t]{2}{*}{ Targeted sanction } & 0.334 & 0.334 & 0.338 & 0.334 & 0.361 \\
\hline & $(0.263)$ & $(0.294)$ & $(0.263)$ & $(0.294)$ & $(0.263)$ \\
\hline \multirow[t]{2}{*}{ Capital distance } & -0.0000343 & -0.0000293 & -0.0000335 & -0.0000318 & -0.0000282 \\
\hline & $(0.0000311)$ & $(0.0000355)$ & $(0.0000308)$ & $(0.0000348)$ & $(0.0000311)$ \\
\hline \multirow[t]{2}{*}{ Issue type $=$ Security } & 0.347 & 0.00764 & 0.364 & 0.0168 & 0.377 \\
\hline & $(0.347)$ & $(0.383)$ & $(0.345)$ & $(0.383)$ & $(0.346)$ \\
\hline \multirow[t]{2}{*}{ Issue type - Economics } & 0.0193 & -0.160 & -0.00178 & -0.171 & -0.00698 \\
\hline & $(0.434)$ & $(0.518)$ & $(0.435)$ & $(0.516)$ & $(0.433)$ \\
\hline \multirow[t]{2}{*}{ Issue type $=$ Human Rights } & -0.445 & -0.342 & -0.429 & -0.334 & -0.439 \\
\hline & $(0.347)$ & $(0.385)$ & $(0.345)$ & $(0.385)$ & $(0.343)$ \\
\hline \multirow[t]{2}{*}{ National Material Capabilities Ratio } & $0.00218^{*}$ & $0.00394 *$ & $0.00236^{*}$ & $0.00419 * *$ & $0.00251^{*}$ \\
\hline & $(0.00107)$ & $(0.00153)$ & $(0.00111)$ & $(0.00159)$ & $(0.00110)$ \\
\hline \multirow[t]{2}{*}{ Post-Cold War threat } & -0.225 & -0.265 & -0.223 & -0.282 & -0.237 \\
\hline & $(0.323)$ & $(0.354)$ & $(0.320)$ & $(0.354)$ & $(0.319)$ \\
\hline \multirow[t]{2}{*}{ Sender $=$ USA } & 0.382 & 0.0401 & 0.347 & 0.0492 & 0.329 \\
\hline & $(0.601)$ & $(0.703)$ & $(0.594)$ & $(0.697)$ & $(0.591)$ \\
\hline \multirow[t]{2}{*}{ Multilateral Institution involved } & 0.343 & 0.233 & 0.300 & 0.229 & 0.307 \\
\hline & $(0.347)$ & $(0.404)$ & $(0.342)$ & $(0.405)$ & $(0.342)$ \\
\hline \multirow[t]{2}{*}{ Sender $=$ Other Autocracy } & $-1.336 * *$ & $-1.409 *$ & $-1.395 * *$ & $-1.417^{*}$ & $-1.396 * *$ \\
\hline & $(0.491)$ & $(0.555)$ & $(0.488)$ & $(0.555)$ & $(0.486)$ \\
\hline \multirow[t]{2}{*}{ Sender $=$ Personalist } & -0.125 & -0.649 & -0.117 & -0.648 & -0.345 \\
\hline & $(0.740)$ & $(0.782)$ & $(0.739)$ & $(0.782)$ & $(0.701)$ \\
\hline \multirow[t]{2}{*}{ Sender's last threat led to target concession } & -0.0291 & -0.0933 & -0.0158 & -0.106 & 0.00837 \\
\hline & $(0.289)$ & $(0.320)$ & $(0.289)$ & $(0.320)$ & $(0.288)$ \\
\hline \multirow[t]{2}{*}{ Multiple episodes at the same time } & -0.0674 & -0.198 & -0.0556 & -0.192 & -0.0895 \\
\hline & $(0.257)$ & $(0.276)$ & $(0.256)$ & $(0.276)$ & $(0.255)$ \\
\hline \multirow[t]{2}{*}{ _cons } & 0.440 & 0.628 & 0.406 & 0.635 & 0.345 \\
\hline & $(0.493)$ & $(0.546)$ & $(0.487)$ & $(0.542)$ & $(0.489)$ \\
\hline $\mathrm{N}$ & 521 & 430 & 522 & 431 & 527 \\
\hline \multicolumn{6}{|l|}{ Standard errors in parentheses } \\
\hline$=" * \mathrm{p}<0.05$ & $* * \mathrm{p}<0.01$ & $* * * \mathrm{p}<0.001 "$ & & & \\
\hline
\end{tabular}




\section{Figure 1 - Predicted Probability of Target Concession When Logged Target Trade Dependence is set to minimum, mean, and maximum and when Target Personalism Index Varies from 0 to 1}

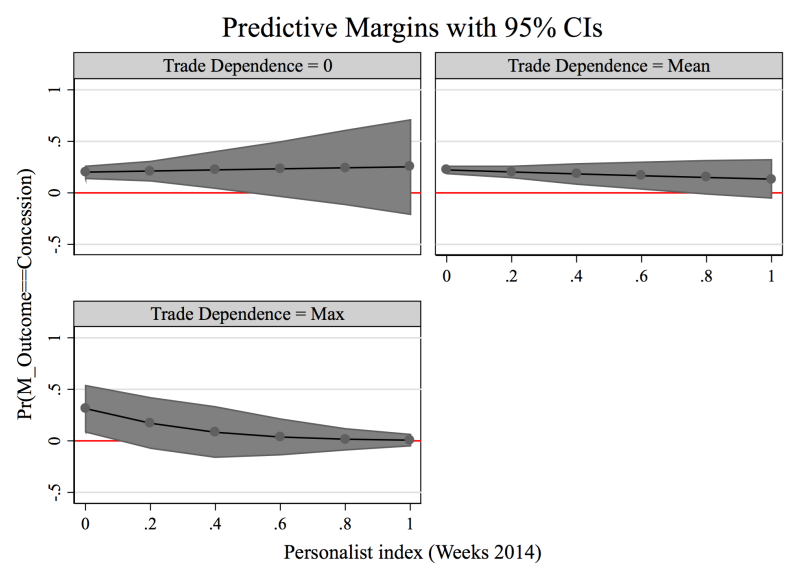

COW Trade

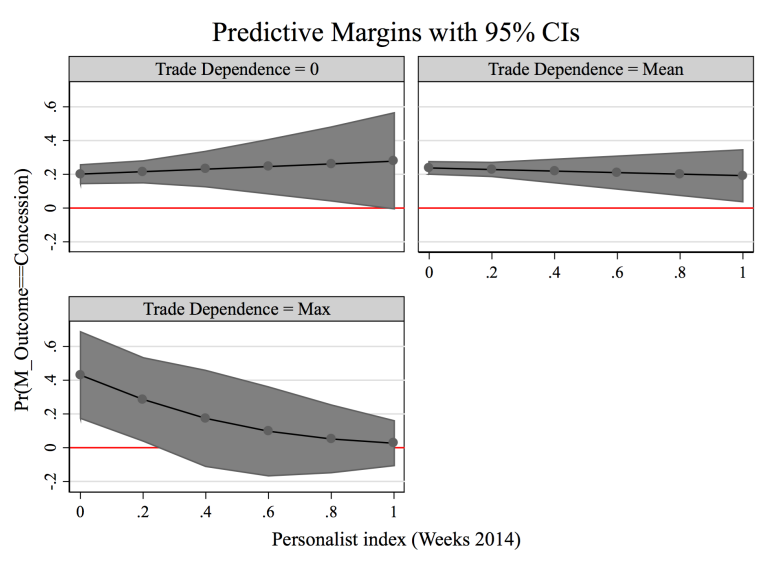

UN Comtrade

The model also shows that material capabilities ratio, issue type and sender's coercive success from the previous episode have effects on sender's probability of conceding at threat stage. For material capabilities, the result is consistent with Morgan and Schwebach (1997) and Krustev (2007) that sender's power relative to target is positively correlated with sanction effectiveness (Bapat et al 2013). For issue type, security issue tends to make targets more less likely to concede. Senders who seek to use sanction threat to contain political influence, change target's military behavior, or solve issues such as territorial dispute are less likely to achieve their goals. Finally, sender's coercive success in the previous episode is positively associated with the probability of 
concession. In other words, sender's "reputation of success" matters in target's calculus over whether to cave in or to fight on. This result is complementary with Peterson's (2013) study of all U.S.-initiated threats, which find that target is less likely to acquiesce when the U.S. recently backed down from a sanction threat. Together, the results are consistent with Weisiger and YarhiMilo's (2015) emphasis on the important of past behaviors in international crises.

\section{Conclusion}

Overall, the empirical evidence supports my argument that personalist institution, through decreasing the leader's domestic audience size, can open way for target recalcitrance and make concessions less likely. Moreover, the results are also consistent with the theoretical precondition: personalist particular behavioral pattern is only observed when target trade dependence on sender is high. While measuring regime type and specifying bilateral trade relationship are both methodological challenges not without debates. ${ }^{7}$ I use two trade data sets, two measurements of target trade dependence, and two different approaches of operationalizing "personalism," to run the same analysis and our interested results remain the same. In addition to personalist recalcitrance, the model also suggests that difference in target-sender material capability, the type of issue that is under dispute, and sender's past behavior all have implications on a target's likely response to a sender's threat.

If the model is correct, the results also provides an alternative explanation to Escribà-Folch and Wright's (2010) finding that personalist leaders are more vulnerable to sanction's stabilizing effect on their regimes. While this theory is not inconsistent with their account that personalist

\footnotetext{
7 See Gartzke and Li (2003) "Measure for Measure: Concept Operationalization and the Trade InterdependenceConflict Debate," Journal of Peace Research, vol. 40, no. 5, 2003, pp. 553-571 Sage Publications (London, Thousand Oaks, CA and New Delhi) and Barbieri and Peters (2003) "Measure for Mis-measure: A Response to Gartzke \& Li," Journal of Peace Research, vol. 40, no. 6, 2003, pp. 713-719. Sage Publications (London, Thousand Oaks, CA and New Delhi).
} 
states tend to be small, oil-rich countries with exploitative institutions relying on unearned income and trade to buy loyalty, the personalist weakness under sanction is also possibly due to the lack of strategic selection - especially when potential cost of a threatened sanction is high. Where weak countries of other regime types decide to cave in, leaving only the stronger ones facing sanction imposition, weaker personalist targets might decide to stand firm regardless of the potential costs and hence generating a weaker sample in the imposition stage.

While previous literature argues that sanction works better against democracies than autocracies, this article provides two refinements. First, not all autocracies are alike and some behave more like democracies than others. If the results here is to be trusted, target recalcitrance more likely to be observed on personalist leaders instead of leaders from military or single party regimes. Second, the article shows the importance of taking "threat stage" into consideration, especially when the goal is to understand sanction's coercive effectiveness, not just its material impact on target society when already imposed. Taken together, empirical evidence from threat stage and imposition stage can arguably make policy makers to make more informed decisions with respect to economic sanctions and coercive diplomacy. 


\section{Reference:}

Baldwin, D. A. (1985). Economic statecraft. Princeton University Press.

Baldwin, D. A. (1999). The Sanctions Debate and the Logic of Choice. International Security, 24(3):80-107.

Bapat, N. A., Heinrich, T., Kobayashi, Y., and Morgan, T. C. (2013). Determinants of Sanctions Effectiveness: Sensitivity Analysis Using New Data. International Interactions, 39(1):79-98.

Bapat, N. A. and Kwon, B. R. (2015). When Are Sanctions Effective? A Bargaining and Enforcement Framework. International Organization, 69(01):131-162.

Barbieri, K. (1996). Economic Interdependence: A Path to Peace or a Source of Interstate Conflict? Journal of Peace Research, 33(1):29-49.

Brooks, R. A. (2002). Sanctions and Regime Type: What Works, and When? Security Studies, 11(4):1-50.

Bueno de Mesquita, B. and Smith, A. (2012). Domestic Explanations of International Relations. Annual Review of Political Science, 15:161-181.

Copeland, D. C. (1996). Economic Interdependence and War: A Theory of Trade Expectations. International Security, 20(4):5-41.

Copeland, D. C. (2014). Economic Interdependence and War. Princeton University Press, Princeton, NJ.

Cortright, D. and Lopez, G. A. (1998). Carrots, Sticks, and Cooperation: Economic Tools of Statecraft. In Rubin, B. R., editor, Cases and Strategies for Preventive Action. New York: The Century Foundation Press.

Dashti-Gibson, J., Davis, P., and Radcliff, B. (1997). On the Determinants of the Success of Economic Sanctions: An Empirical Analysis. American Journal of Political Science, 41(2):608-618.

Downes, A. B. and Sechser, T. S. (2012). The Illusion of Democratic Credibility. International Organization, 66(03):457-489.

Doyle, M. W. (1986). Liberalism and world politics. American Political Science Review, 80(04): $1151-1169$.

Drezner, D. W. (2015). Targeted Sanctions in a World of Global Finance. International Interactions, 41(4):755-764.

Drury, A. C. (1998). Revisiting Economic Sanctions Reconsidered. Journal of Peace Research, 35(4):497- 509.

Drury, A. C. and Peksen, D. (2014). Women and Economic Statecraft: The Negative Impact International Economic Sanctions Visit on Women. European Journal of International Relations, 20(2):463-490.

Escribà-Folch, A. (2012). Authoritarian Responses to Foreign Pressure Spending, Repression, and Sanctions. Comparative Political Studies, 45(6):683-713.

Escribà-Folch, A. and Wright, J. (2010). Dealing with Tyranny: International Sanctions and the 
Survival of Authoritarian Rulers. International Studies Quarterly, 54(2):335-359.

Fearon, J. D. (1994). Domestic political audiences and the escalation of international disputes. American Political Science Review, 88(03):577-592.

Galtung, J. (1967). On the Effects of International Economic Sanctions: With Examples from the Case of Rhodesia. World Politics, 19(3):378-416.

Geddes, B. (2003). Paradigms and sand castles: Theory building and research design in comparative politics. University of Michigan Press.

Geddes, B., Wright, J., and Frantz, E. (2014). Autocratic Breakdown and Regime Transitions: A New Data Set. Perspectives on Politics, 12(02):313-331.

Horowitz, M., McDermott, R., and Stam, A. C. (2005). Leader Age, Regime Type, and Violent International Relations. Journal of Conflict Resolution, 49(5):661-685.

Hufbauer, G. C., Schott, J. J., Elliott, K. A., and Oegg, B. (2007). Economic Sanctions Reconsidered. Washington, DC: Peterson Institute for International Economics.

Kaempfer, W. H. and Lowenberg, A. D. (2007). The Political Economy of Economic Sanctions. In Keith Hartley and Todd Sandler, editors, Handbook of Defense Economics. Elsevier.

Lai, B. and Slater, D. (2006). Institutions of the Offensive: Domestic Sources of Dispute Initiation in Authoritarian Regimes, 1950-1992. American Journal of Political Science, 50(1):113-126.

Lektzian, D. and Souva, M. (2007). An Institutional Theory of Sanctions Onset and Success. Journal of Conflict Resolution, 51(6):848-871.

Lenway, S. A. (1988). Between War and Commerce: Economic Sanctions as a Tool of Statecraft. International Organization, 42(02):397-426.

Marinov, N. (2005). Do Economic Sanctions Destabilize Country Leaders? American Journal of Political Science, 49(3):564.

Martin, L. L. (1992). Coercive Cooperation: Explaining Multilateral Economic Sanctions. Princeton University Press, Princeton, N.J.

Martin, L. L. (2000). Democratic Commitments. Princeton University Press, Princeton, N.J. Mearsheimer, J. J. (1992). Disorder Restored. In Allison, G. T. and Treverton, G. F., editors, Rethinking America's Security. New York: W. W. Norton.

Mertens, W. G. (2000). Economic Sanctions in a Dictatorship Model. Center for Economic Analysis, Department of Economics, University of Colorado at Boulder, pages 1-34.

Miyagawa, M. (1992). Do Economic Sanctions Work? New York, NY: St. Martin's Press.

Morgan, T. C., Bapat, N., and Kobayashi, Y. (2014). Threat and Imposition of Economic Sanctions 1945 - 2005: Updating the TIES dataset. Conflict Management and Peace Science, 31(5).

Morgan, T. C. and Schwebach, V. L. (1997). Fools Suffer Gladly: The Use of Economic Sanctions in International Crises. International Studies Quarterly, 41(1):27-50.

Nooruddin, I. (2002). Modeling Selection Bias in Studies of Sanctions Efficacy. International Interactions, 28(1):59-75.

Pape, R. A. (1997). Why Economic Sanctions Do Not Work. International Security, 22(2):90-136. Peceny, M., Beer, C. C., and Sanchez-Terry, S. (2002). Dictatorial peace? American Political 
Science Review, 96(01):15-26.

Peceny, M. and Butler, C. K. (2004). The Conflict Behavior of Authoritarian Regimes. International Politics, 41(4):565-581.

Peterson, T. M. (2013). Sending a Message: The Reputation Effect of US Sanction Threat Behavior. International Studies Quarterly, 57(4):672-682.

Russett, B. (1994). Grasping the democratic peace: Principles for a post-Cold War world. Princeton University press.

Schelling, T. C. (1958). International Economics. Allyn and Bacon, Boston.

Schelling, T. C. (1960). The Strategy of Conflict. Cambridge, Mass.

Schelling, T. C. (2008). Arms and Influence: With a New Preface and Afterword. Yale University Press. Schultz, K. A. (1999). Do Democratic Institutions Constrain or Inform? Contrasting Two Institutional

Perspectives on Democracy and War. International Organization, 53(02):233-266.

Smith, A. (1995). The success and use of economic sanctions. International Interactions, 21(3):229-245. Tomz, M. (2007). Domestic Audience Costs in International Relations: An Experimental Approach. International Organization, 61(04):821-840.

Tsebelis, G. (1990). Are Sanctions Effective? A Game-theoretic Analysis. Journal of Conflict Resolution, 34(1):3-28.

van Bergeijk, P. A. (1994). Economic Diplomacy, Trade, and Commercial Policy: Positive and Negative Sanctions in a New World Order. Aldershot, UK: Edward Elgar.

Weeks, J. L. (2008). Autocratic audience costs: Regime type and signaling resolve. International Organization, 62(01):35-64.

Weeks, J. L. (2014). Dictators at War and Peace. Cornell University Press.

Weisiger, A. and Yarhi-Milo, K. (2015). Revisiting Reputation: How Past Actions Matter in International Politics. International Organization, 69(02):473-495.

Weiss, J. C. (2014). Powerful patriots: nationalist protest in China's foreign relations. Oxford University Press.

Whang, T., McLean, E. V., and Kuberski, D. W. (2013). Coercion, information, and the success of sanction threats. American Journal of Political Science, 57(1):65-81.

Wood, R. M. (2008). A Hand upon the Throat of the Nation: Economic Sanctions and State Repression, 19762001. International Studies Quarterly, 52(3):489-513.

Wright, J. (2008). Do Authoritarian Institutions Constrain? How Legislatures Affect Economic Growth and Investment. American Journal of Political Science, 52(2):322-343. 


\section{Appendix: (The following materials are designed to accompany the article "Source of Autocratic Recalcitrance to Sanction Threats.”)}

Table 2: Final Outcomes in TIES Dataset

\begin{tabular}{|l|l|}
\multicolumn{2}{l}{ Threat Stage } \\
\hline $\begin{array}{l}\text { Concession at threat } \\
\text { stage }\end{array}$ & $\begin{array}{l}\text { Complete acquiescence by target } \\
\text { Partial acquiescence by target }\end{array}$ \\
\hline $\begin{array}{l}\text { Non-concession at } \\
\text { threat stage }\end{array}$ & $\begin{array}{l}\text { Stalemate } \\
\text { Negotiated settlement } \\
\text { Capitulation by the sender }\end{array}$ \\
\hline Imposition & $\begin{array}{l}\text { Composition Stage } \\
\text { Partial acquiescence by target } \\
\text { Stalemate } \\
\text { Negotiated settlement } \\
\text { Capitulation by the sender }\end{array}$ \\
\hline
\end{tabular}

For COW Trade (1) and UN Comtrade (2), target trade dependency is operationalized in the way below.

$$
\text { Trade Dependence }_{i}=\frac{\text { Dyadic }_{\text {Trade }} \text { Detal }_{\text {Trade }}}{\text { Trj }_{\text {Tota }}}
$$

Alternative COW (3) and Alternative UN (4), I only look at the proportion of target's export to sender to the target's total export volume in a given year.

$$
\text { Trade Dependence }=\frac{\text { Target export to Sender }}{\text { Total Target Export }}
$$

I also generate the predicted probability for model (2) to (5) as I did for model (1) in Figure 1 of this article:

Appendix Figure 1: Predicted Probability of Target Concession When Logged Target Trade Dependence to the sender increases from minimum to maximum 


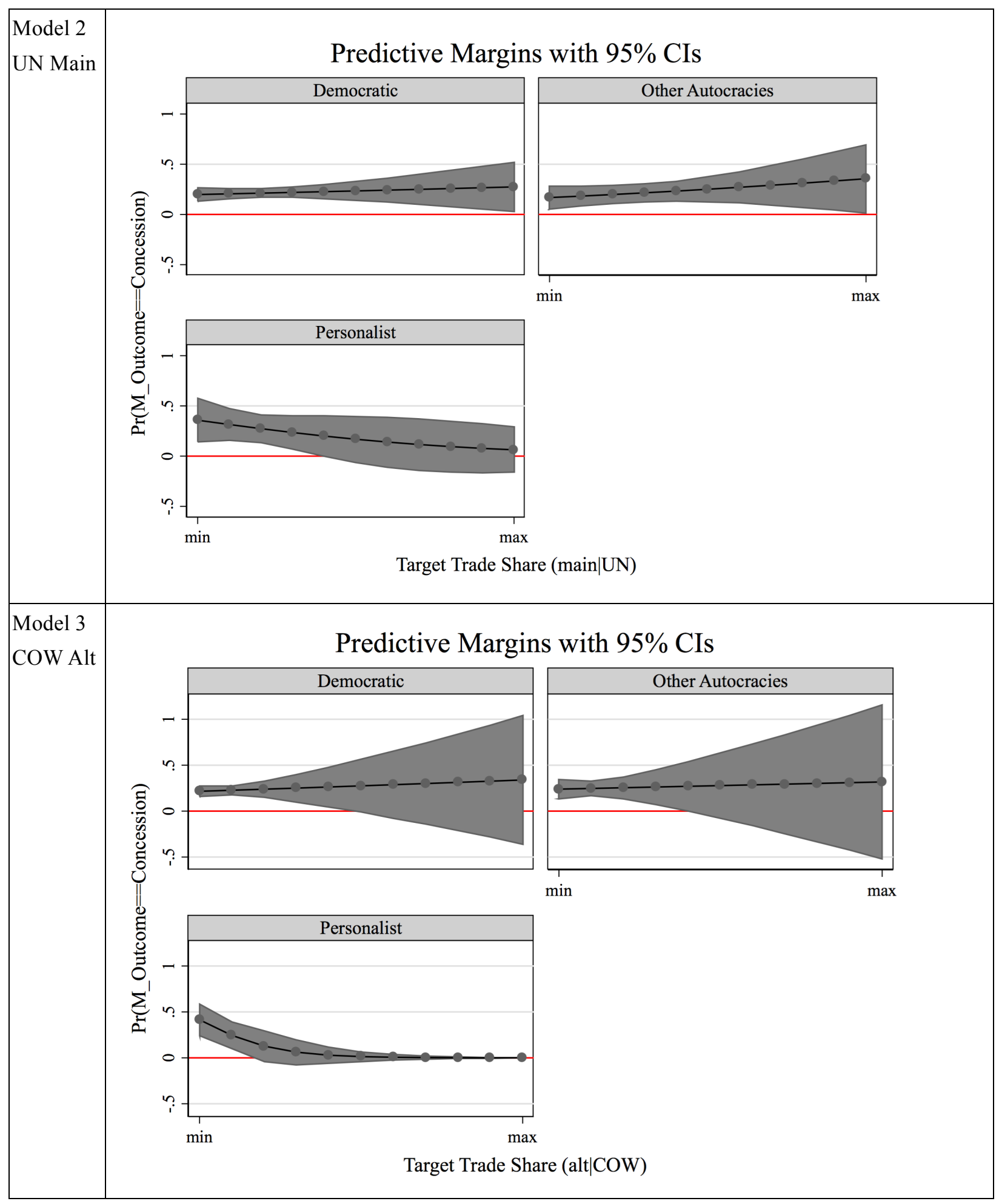




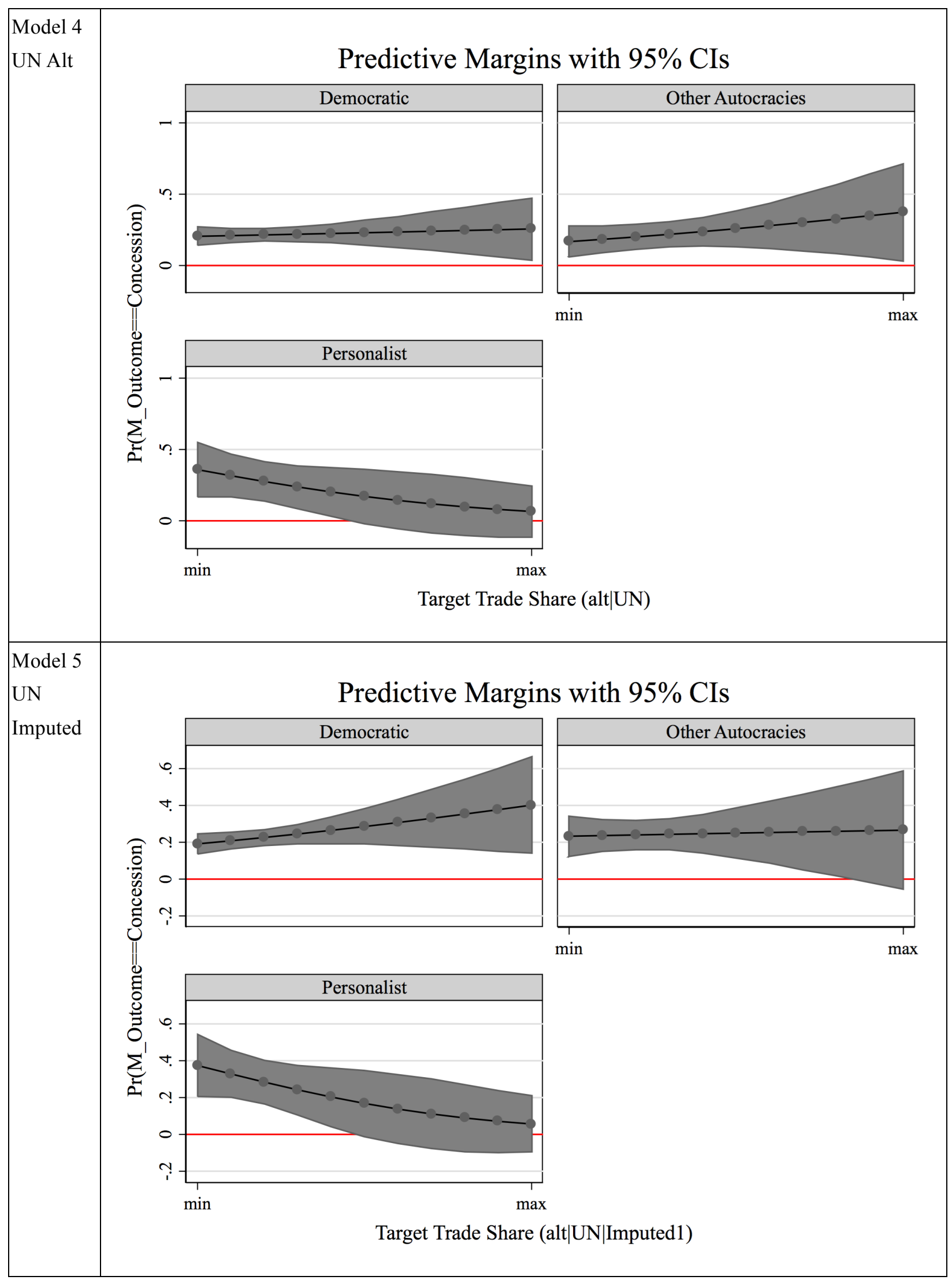




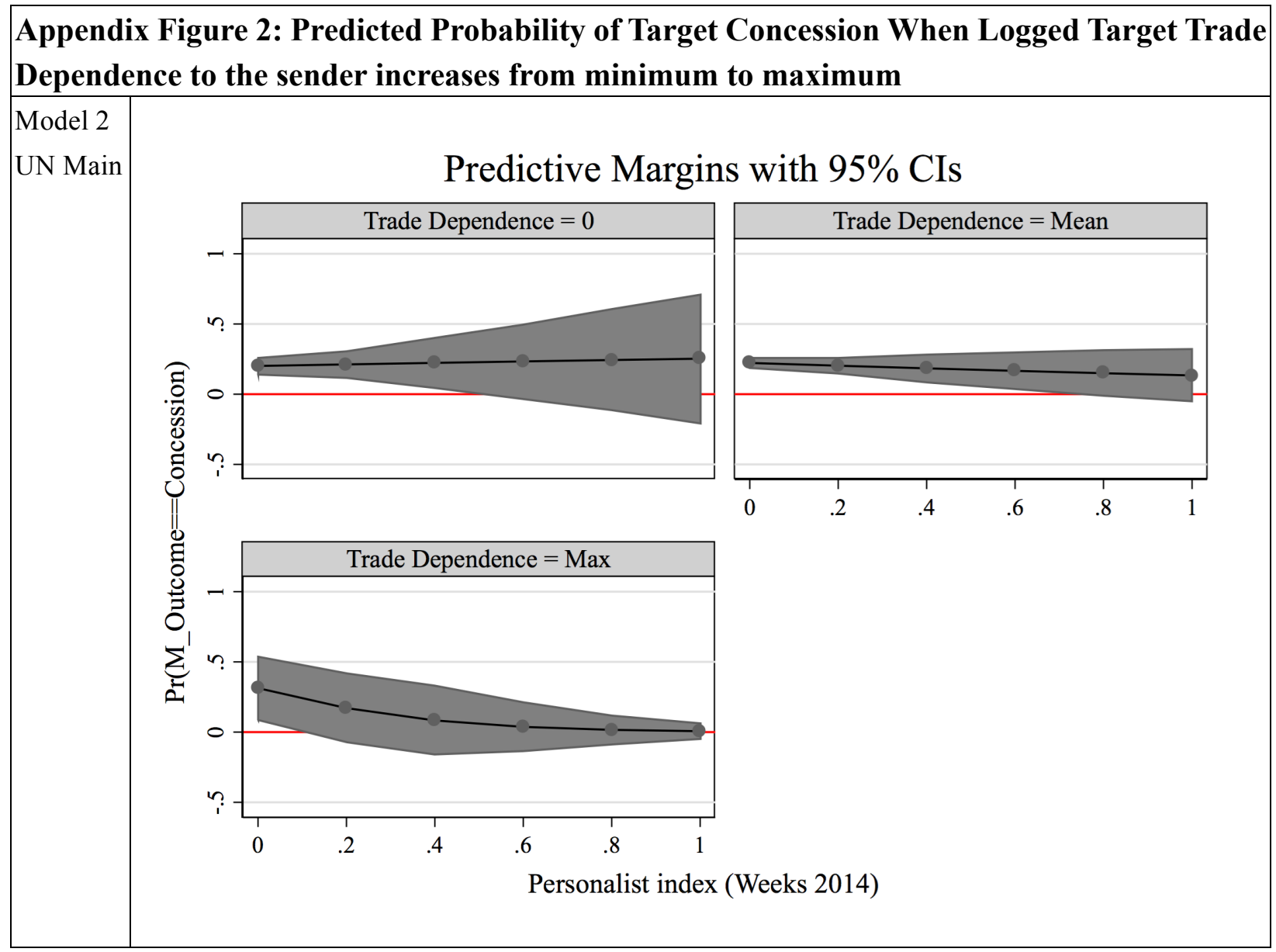




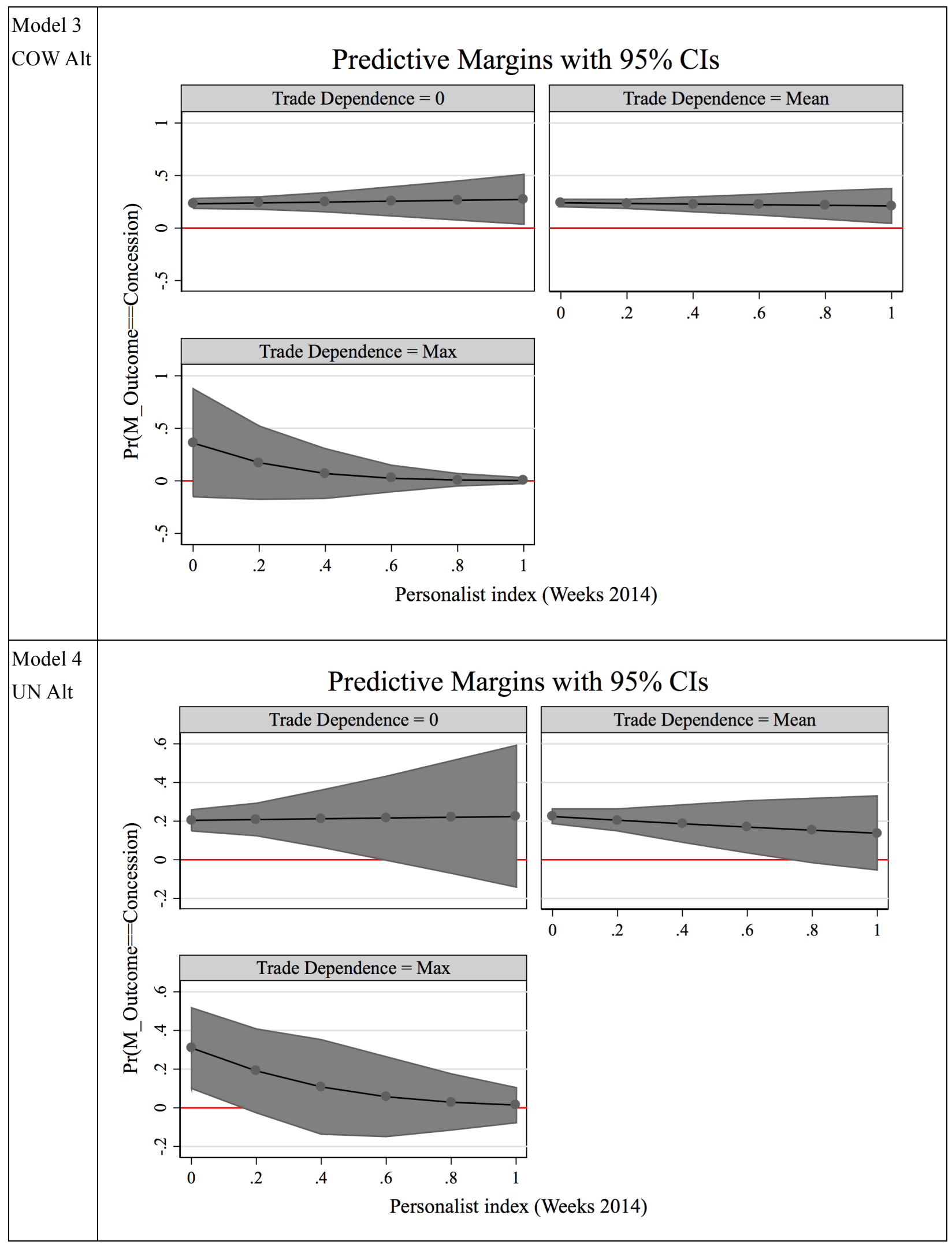




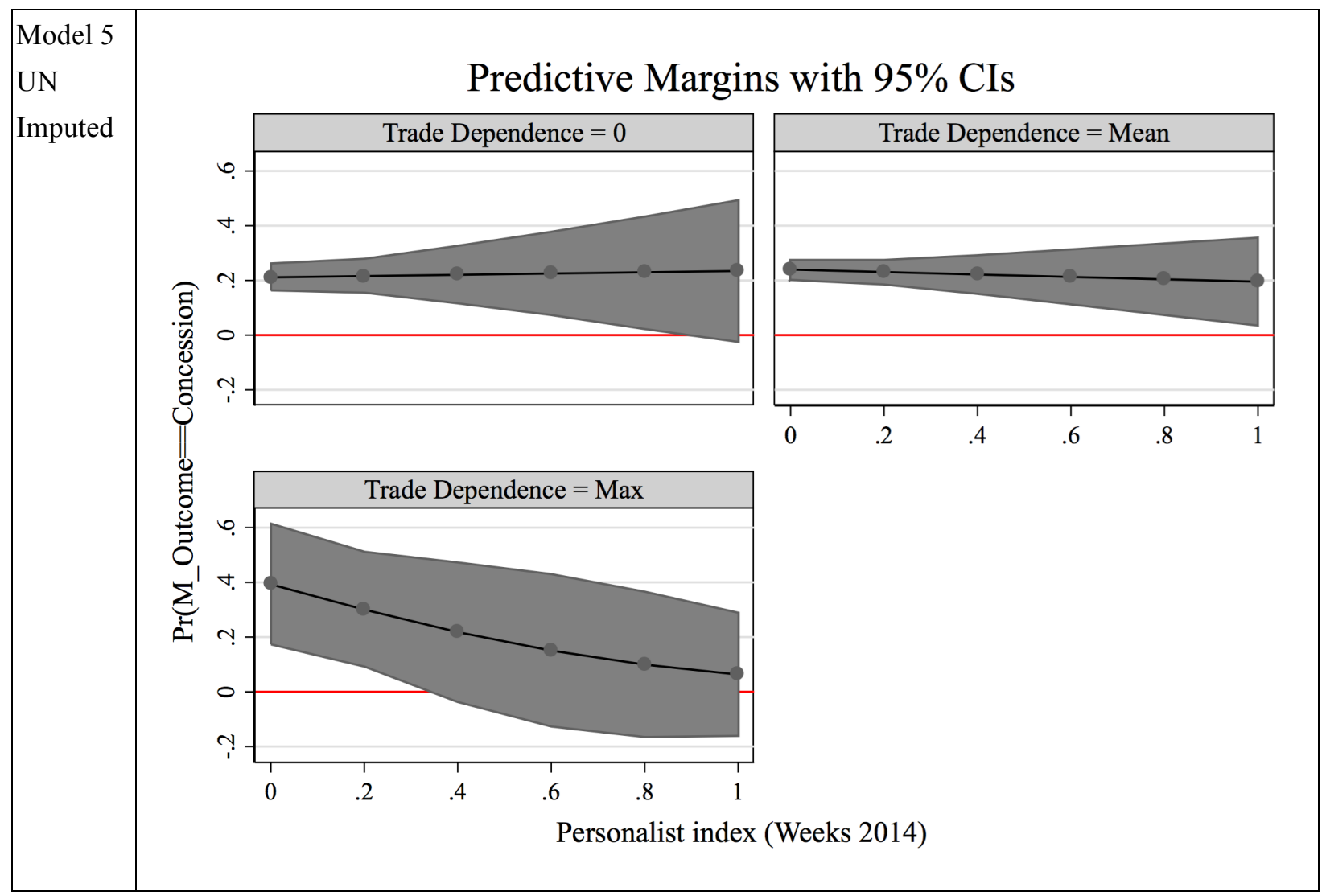

Figure 4 - Predicted Probability of Target Concession when CINC Ratio between Sender and Target Varies from the $1^{\text {st }}$ percentile to the $95^{\text {th }}$ percentile. 
Predictive Margins with 95\% CIs

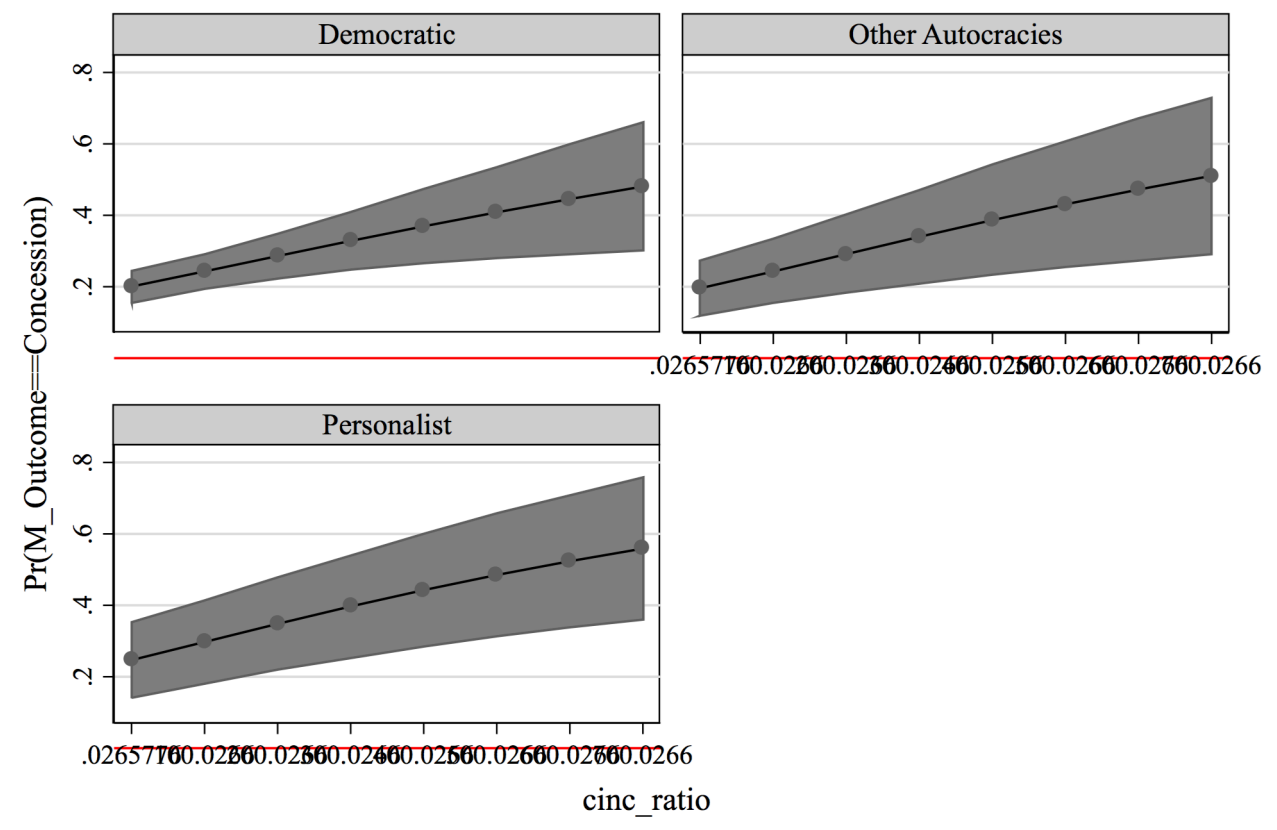

Figure 5 - Predicted Probability of Target Concession Across Issue Types

Predictive Margins with 95\% CIs

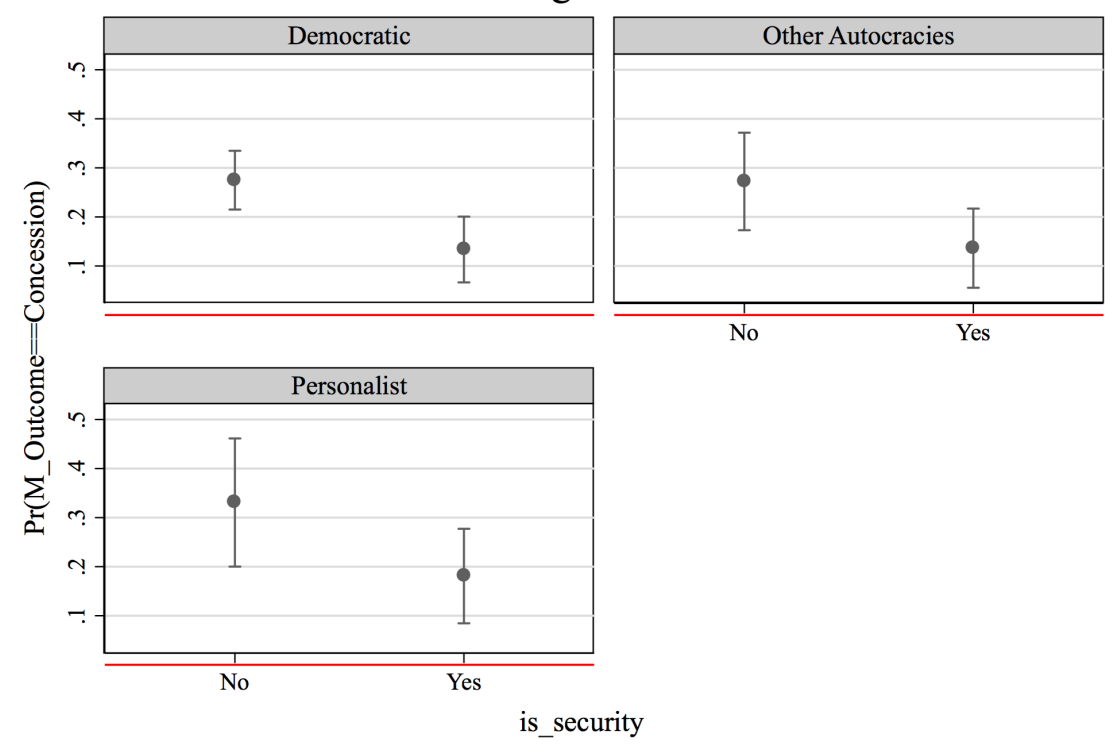

Figure 6 - Predicted Probability of Target Concession when Sender's Last Sanction Threat Resulted in Target Capitulation Varies from 0 to 1 


\section{Predictive Margins with 95\% CIs}

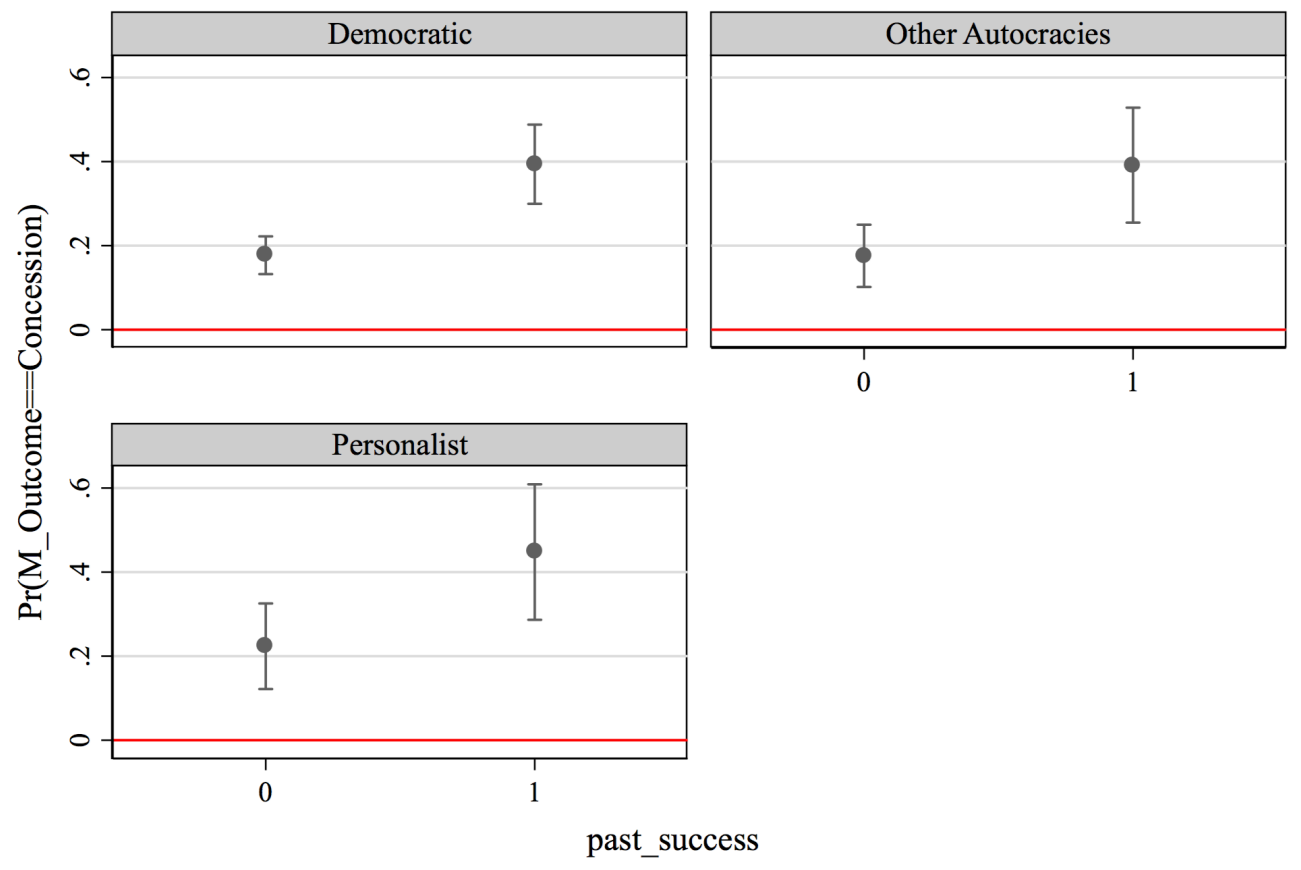

